\title{
Dragon Meets Camel: An Exploration of China's Engagement with Eritrea
}

\author{
Dr Fikresus Amahazion \\ Eritrean Center for Strategic Studies, Asmara, Eritrea \\ fikrejesus87@gmail.com
}

\begin{abstract}
Over the past several decades, the People's Republic of China's engagement with African countries has grown tremendously. China has emerged as Africa's largest trading partner, while Chinese investment and lending to African countries has grown rapidly. In Eritrea, a young, developing country located in the Horn of Africa, Chinese involvement has also considerably increased in recent years. However, although there has been extensive study of China's partnerships across the continent, very little work has been dedicated to examining its ties with Eritrea. What are the history and current scale of involvement? What has been the impact of this engagement on Eritrean society? What are locals' overall perceptions about the relationship or about China more generally? Utilizing a mix of qualitative research methods, including surveys, the current paper explores China's engagement with Eritrea, adding to the voluminous, ever-growing body of literature and helping to diversify and deepen understanding of this important topic. Additionally, although various narratives about the China-Africa relationship have arisen, often led and framed by non-Africans, the present study broadens the discussion by offering local, African perspectives on China-Africa links. Engagement and cooperation between China and Eritrea are longstanding and extend to numerous areas, driven by a range of interests, while local perceptions are quite nuanced and largely consistent with many cross-national studies.
\end{abstract}

Keywords: Africa; China; Development; Economy; Eritrea; Investment; Politics; Trade

\section{Introduction}

Over the past several decades, the People's Republic of China's (PRC, hereafter China) engagement with African countries has grown tremendously. China has emerged as Africa's largest trading partner, while Chinese investment in and lending to African countries has also grown rapidly. Across trade, investment, infrastructure financing, and aid, no other country have such depth and breadth of engagement in Africa (China State Council, 2021; Dollar, 2016; Sun, Jayaram, and Kassiri, 2017; Stein and Uddhammar, 2021). The relationship has also broadened to reach into an array of other sectors, including culture, digital infrastructure and technology, military and security, and health cooperation (Benabdallah, 2016; China Foresight, 2021; China State Council, 2021; Tugendhat and Voo, 2021; King, 2019). A myriad of intertwined factors has driven and shaped China-Africa engagement.

For China, African countries help it to meet its strategic need for natural resources, offer new potential markets and an opportunity to support the restructuring of its own economy, and represent a key support bloc for its "One-China Principle" and foreign policy agendas in international organizations. ${ }^{1}$ On the other hand, for many African countries, China offers the benefit of unconditional loans and access to capital, while greater Chinese engagement has often been associated with better economic performance and growth, helped address critical infrastructure and development gaps, and presented important other economic opportunities (Calabrese and Tang, 2020; Cooke et al., 2015; Sun, 2014; Sun et al., 2017; Tull, 2006). ${ }^{2}$ However, the considerable growth and deepening of China's activity in Africa have not unfolded completely without criticism or controversy. There have been concerns raised about an impending debt crisis and "debt-trap diplomacy," which have received push back and are regarded as overly simplified or lacking nuance (Brautigam, 2009; 2019a; 2019b; Eom, Brautigam, and Benabdallah, 2018; Jones and Hameiri, 2020; Ryder and Fu, 2021; Shaomin and Jiang, 2020). Moreover, China's engagement across the continent has at times been described as exploitative or neocolonial and frequently criticized for a lack of transparency.

A failure to promote good governance or human rights, and poor labor and environmental practices (Brautigam et al., 2017; Dollar, 2016; Raine, 2009). In 2011, Hillary Clinton, then US Secretary of State, warned about the "new colonialism" by China in Africa (Quinn, 2011), while at a 2018 policy briefing, then US National Security Adviser John Bolton condemned China's activities in Africa, alleging that, "China uses bribes, opaque agreements, and the strategic use of debt to hold states in Africa captive to Beijing's wishes and demands" (Gearan, 2018). Africans, too, have at times expressed strong opposition to and critiques of China's 
growing activities on the continent (Hanauer and Morris, 2014; Polgreen and French, 2007). ${ }^{3}$ At the same time, although many portrayals of China's engagement across the continent tend to be negative and highly critical, findings from numerous empirical studies and public opinion surveys suggest the situation is much more nuanced, with Africans' attitudes about China being variegated, complex, and often actually quite positive (Afrobarometer, 2016; 2020; 2021; Dollar, 2016; Pew Research Center, 2019; Rebol, 2010; Sautman and Hairong, 2009). In Eritrea, a young, developing country located in the Horn of Africa, Chinese involvement and cooperation have considerably increased in recent years.

Yet, while there has been extensive study of China's partnerships across much of the rest of the continent, relatively, little is known about its engagement with Eritrea. What are the general history and current scale of involvement? What has been the impact of this engagement on Eritrean society? What are locals' overall perceptions about the relationship or about China more broadly? Utilizing a mix of qualitative research methods, including surveys, this paper explores China's engagement with Eritrea, adding to the voluminous, ever-growing body of literature on China-Africa relations and helping to diversify and deepen understanding of this important topic. Furthermore, while various narratives have emerged about the China-Africa relationship, for the most part, led and framed by non-Africans, the present study broadens the discussion by providing local, African perspectives on China-Africa links. As the first study dealing with the topic in Eritrea, the present paper also represents an important starting contribution and serves as a useful foundation for future research. The outline of the rest of the paper is as follows. In the next section, a general overview of the literature is provided, followed by a review of the methods. Subsequently, the results and discussion are presented. The last section concludes and raises several recommendations for future study.

\section{Literature Review}

Historical Background: China's engagement with Africa is not new, dating back centuries and spanning a number of ancient dynasties (Jinyuan, 1984; Peterson, 1994). However, its modern ties with Africa can be traced back to the earliest years of African independence in the 1950s and 1960s. In 1956, Egypt became the first African country to establish diplomatic relations with China. Many other African countries quickly followed suit, and in the mid-1960s then Chinese Premier Zhou Enlai paid official visits to 11 countries in Africa. For the most part, China's role at the time was ideologically motivated and included support for national liberation movements, various forms of humanitarian assistance, and direct state-to-state aid. Of note, this support was extended despite China's own limited wealth and challenging economic circumstances. ${ }^{4}$ Another important factor underlying China's assistance to African countries was its attempt to secure diplomatic recognition for the PRC over Taiwan (Republic of China) at the United Nations (UN). China rewarded countries that sided with Beijing instead of Taipei.

When UN member states voted to recognize China during the $26^{\text {th }}$ session of the UN General Assembly in October of 1971, 26 of the 76 votes came from African nations (FMPRC, 2004; Snow, 1989; Sun et al., 2017; Taylor, 1998). In response, Chairman Mao is purported to have said, "We were brought back into the United Nations by our black African friends" (Li, 2007: 78). Over the next several decades, due to a combination of factors, including poor overall results and prospects across the continent, limited funds, internal developments, and the prioritization of domestic reform and economic progress, China considerably scaled back its aid and general outreach to Africa. The continent's importance to China was additionally marginalized as Chinese tensions with the Soviet Union and the USA were decreasing, and China slowly began opening up to the rest of the world. China's influence and interest in Africa also waned as many African leaders sought to maintain a non-aligned position (Brautigam, 1998; Shinn and Eisenman, 2012: 45; Taylor, 1998: 443-44; Taylor, 2010). Chinese interest in Africa was reignited by the fallout of the Tiananmen Square protests in June 1989, when many African leaders supported Beijing in the face of intense criticism by the West.

The large student-led protests, which carried on for weeks and were mainly centered on calling for democracy, free speech, and freedom of the press in China, were finally halted through the government's harsh, bloody crackdown, known as the Tiananmen Square Massacre, on June 4 and 5. The events sparked an international outcry and condemnations. The UN Secretary-General raised concerns with the Chinese ambassador, while many states, particularly from the West, condemned the crackdown and imposed 
economic sanctions and arms embargoes against China. Less than a month after the massacre, the United States Congress voted to impose economic sanctions against China, citing human rights violations. Facing international isolation, sanctions, and a tarnished global image, China remembered Africa was a useful support constituency if and when it was in dispute with other global actors, and also as a site where Beijing could continue to marginalize Taiwan. In addition, as Africa's economic reform programs started gaining momentum in the 1990s, the continent quickly regained prominence in China's overall foreign policy, and China began to increase political cooperation and strengthen economic ties with African countries (Sun, 2014; Taylor, 1998; 2004; 2006).

In 2000, the Forum on China-Africa Cooperation (FOCAC) was established, helping to strengthen China's links with Africa and advance them to a higher level. Since its establishment, FOCAC, which convenes triennially and alternates host sites between China and Africa, has become an important high-level platform for dialogue between China and Africa and an effective mechanism to promote stronger trade and investment relations between China and African countries in both the government and private sectors. Later, in 2013, Chinese President Xi Jinping launched the Belt and Road Initiative (BRI), a vast network of transportation, energy, and telecommunications infrastructure linking Europe, Africa, and Asia. The multi-billion-dollar initiative has created new policies and funding to deepen investment, infrastructure, and trade ties between China and Africa (China Policy Paper, 2015; China State Council, 2021; Hurley, Morris, and Portelance, 2018). Today, China has become Africa's most important economic partner. It is the continent's leading trading partner (eclipsing the US in 2009 and remaining Africa's top partner every year since), while Chinese investment in and lending to African countries has grown rapidly. According to the China Africa Research Initiative (CARI), a leading global source of aggregated data on China-Africa economic relations, in 2019 the total volume of Africa-China trade was approximately US\$192 billion, a massive jump from 1992.

When it was about US $\$ 1.75$ billion (CARI, 2022). More recent figures, available from the UN Comtrade database and official Chinese sources, show that the volume of China-Africa trade was about US\$187 billion in 2020 , and in 2021, just for the period spanning January to September, it was about US\$185.2 - representing a year-on-year record (China State Council, 2021; UN Comtrade, 2022). In a similar fashion, Chinese foreign direct investment (FDI) surged from approximately US\$75 million in 2003 to about US\$4.2 billion in 2020, while between 2013 and 2018; nearly 45 percent of China's total global foreign aid expenditure went to Africa, mainly in the form of grants, interest-free loans, and concessional loans. In total, between 2000 and 2019, it is estimated that Chinese financiers signed 1,141 loan commitments worth US\$153 billion with African governments and state-owned enterprises (CARI, 2022; China State Council, 2021)..$^{5}$ Importantly, Chinese assistance has extended to helping address Africa's critical infrastructure gap, particularly through supporting the building or renovation of countless dams, stadia, bridges, hotels, roads, railways, airports, ports, telecommunications networks, hospitals and health facilities, schools, and other infrastructure.

From 2000 to 2020, China helped African countries build more than 13,000 kilometers of roads and railways and more than 80 large-scale power facilities, and it funded over 130 medical facilities, 45 sports venues, and over 170 schools (China State Council, 2021). Additionally, education and health have been areas of focus, with China providing African countries with thousands of scholarships and short-term training opportunities to African students, as well as billions of dollars for health projects, facilities, equipment, and programs. Over a period of several decades, numerous Chinese medical teams have volunteered across the continent, providing important, often life-saving, services and training to locals (China State Council, 2021; Chen et al., 2019; Lin et al., 2016) (Figures 1-4 Here).

In early 2020, following the emergence of the coronavirus disease (COVID-19) global pandemic, ${ }^{6}$ China was quick to step in with substantial aid and support to African nations. ${ }^{7}$ The Chinese government, alongside private companies and individuals, donated masks, testing kits, face shields, respirators, protective suits, and other medical equipment critically needed to fight the spread of COVID-19. Additionally, China provided extensive prevention and control support to various organs of the African Union (AU), deployed medical teams to the continent to offer help and train locals, and organized video conferences to share valuable COVID-19 response experiences (China State Council, 2021; Nantulya, 2021; Shurkin, Noyes, and Adgie, 2021). In June 2020, the "Extraordinary China-Africa Summit on Solidarity against COVID-19" was held, making China the only major country that convened a summit with countries across Africa in 2020 (Xinhua, 
2020). After a vaccine for COVID-19 was eventually developed, China began supplying vaccines to dozens of African countries, while declaring its commitment to the local production of vaccines on the continent. Significantly, with Africa confronted by substantial social, economic, and other challenges, leading to the region's first recession in 25 years (AfDB, 2021a; World Bank, 2021a), a lot of Chinese-financed and supported projects across the continent maintained operation.

While China also extended a number of African countries' considerable debt restructuring or cancellations. China has additionally committed to reinforcing economic relations with Africa after the pandemic, such as investments in the digital economy, boosting renewable energies, and expanding the $5 \mathrm{G}$ network (China State Council, 2021; Xinhua, 2020). As part of the 2021 FOCAC meeting in Senegal, President Xi Jinping also pledged to ramp up support by providing another billion doses of vaccines to African countries, as well as extend a range of financial support measures to African countries and financial institutions, from credit lines and trade financing to the allocation of special drawing rights from global institutions (FOCAC, 2021). In recent years, China has steadily expanded its peacekeeping, military, and security footprint across Africa. Since 2008, it has supported counterpiracy operations in the Gulf of Aden, while Chinese peacekeepers and personnel have participated in various missions, including in the Central African Republic, the Democratic Republic of Congo (DRC), Liberia, Sierra Leone, South Sudan, Sudan, and Mali. In a September 2015 speech at the UN General Assembly, Chinese President Xi Jinping pledged to provide US $\$ 100$ million to create an AU standby force (MFA, 2015). In August 2017, China opened its first overseas military base in Djibouti (with reports of plans for more); ${ }^{8}$ while in July 2019 Beijing hosted the first China-Africa Peace and Security Forum, bringing together nearly 100 security officials from 50 African countries and the AU.

Notably, China has developed direct defense and security cooperation with African counterparts, directs a significant part of its military assistance (e.g., funds, equipment, and training) towards sub-regional organizations, and is a major supplier of arms to African countries (Duchâtel, Gowan, and Rapnouil, 2016; Large, 2016; Taylor, 2004; Zürcher, 2019). There have also been increasing reports in recent years of Chinese plans to establish a permanent military installation on Africa's Atlantic coast, possibly in the small Central African country of Equatorial Guinea (Phillips, 2021; The Economist, 2021). China's growing military and security engagement and presence on the continent are driven by a number of factors. While Western donors and international financial institutions tend to condition support on democracy. These include advancing its foreign policy goals and safeguarding its substantial and growing economic interests and investments, protecting Chinese citizens, strengthening multilateralism and the UN system, promoting stability, enhancing its reputation as a benevolent rising superpower actively engaged within the UN system, extending its diplomatic influence and soft power, training its personnel and acquiring much-needed skills or experience, and testing new military equipment (Benabdallah, 2020; Cabestan, 2018; Duchâtel et al., 2016; Fleurant et al., 2016; Zürcher, 2019). ${ }^{9}$

Issues within the China-Africa Relationship: For many African countries, China is an attractive partner due to its explicit "non-interference" principle, which offers them greater policy space and allows them to maintain, sovereignty over their development strategy. While Western donors and international financial institutions tend to condition support on democracy, human rights, economic liberalism, and good governance, ${ }^{10}$ China extends loans, grants, investment, and other assistance with interest rates significantly below market value, no political strings, and a pledge not to interfere in their internal affairs (Alden, 2007: 44; Brautigam, 2011; Breslin, 2007: 2; Naidu and Davies, 2006: 80; Obiorah, 2007; Regilme Jr. and Hodzi, 2021). However, there is also some empirical evidence indicating that China may similarly condition its assistance to Africa on support for its foreign policy objectives, such as voting at the UN and its "One-China Principle" (Dreher et al., 2018; Dreher and Fuchs, 2015; Strüver, 2016). Furthermore, for many African countries, China, as a formerly poor, mostly agrarian country that has experienced foreign invasion, plunder, and enslavement by foreign powers before later going on to achieve rapid economic growth.

Massive poverty reduction, and development, represent a viable and attractive model (Cabestan, 2012; Hodzi, 2018). ${ }^{11}$ In 2008, former Senegalese President Abdoulaye Wade made this point, stating that, "The Chinese model has much to teach Africa" (Wade, 2008), while in 2018, during his opening address at the FOCAC summit in Beijing, South African President Cyril Ramaphosa explained that, "There are many valuable lessons that Africa can learn from China's impressive growth model and its approach to meeting the needs of its 
people" (RSA, 2018). Many other leaders, officials, and notable figures from across the continent have expressed similar views (Shangwe, 2017; The Economist, 2010). One persistent criticism of Chinese engagement in Africa has been that many projects built on the continent overwhelmingly rely on Chinese labor or resources, and fail to encourage local linkages (Alden, 2007; Cabestan, 2012; Corkin, 2012; Rocha, 2007). The reality, however, is more complicated, with much empirical work demonstrating that Chinese engagement can contribute to job creation, skills development, and technology and knowledge transfer (Brautigam, 2015; Brautigam et al., 2017; Calabrese and Tang, 2020; Chen et al., 2016; Sun et al., 2017; Tang, 2016). ${ }^{12}$ Moreover, it is well to recall that some local African companies often lack the capacity for large projects.

While both local and Chinese officials frequently point to Chinese firms' cost-effectiveness, administrative efficiency, and speed of delivery (Sun et al., 2017). Another topic of controversy has been the influx of Chinese exports into African markets, with critics claiming that it overwhelms local producers with large volumes of cheap products that are difficult to compete with (Taylor, 2010: 192; Warmerdam and Van Dijk, 2016; Waweru, 2021). For instance, in the past, South African trade unions claimed imports from China closed more than 800 companies in their country and left 60,000 workers unemployed (Alden, 2007), while Edwards and Jenkins (2015a; 2015b) found that increased Chinese import penetration into African markets significantly reduced South Africa's regional exports by 20 percent, manufacturing output by 5 percent, and manufacturing employment by 8 percent. Interestingly, in a study of the period from 1995 to 2005, Giovannetti and Sanfilippo (2016) also found that Chinese exports crowd-out African manufacturers not just locally, but in third markets as well. However, some points are worth bearing in mind. In particular, Africans are themselves actively facilitating the penetration of Africa by Chinese-manufactured products, and it is the failure of African economies to industrialize and develop that means they produce very few processed goods and are thus a natural target for Chinese exporters (Taylor, 2010: 192-93).

As well, the influx of Chinese products has benefited African consumers by allowing them to access new products and services that were previously unaffordable or inaccessible (Haroz, 2011; Sigalla, 2014; Zafar, 2007).$^{13}$ Another topic of concern and controversy has been China's longstanding engagement with corrupt, authoritarian governments (e.g., Angola, DRC, Sudan, and Zimbabwe). Through supporting weak, authoritarian, and repressive governments, it is alleged that China helps these regimes stay in power and gain legitimacy, while also potentially undermining long-term stability in those countries (Alden, 2007: 66; Taylor, 2010: 192). ${ }^{14}$ In addition, there have been instances of environmental violations by Chinese-owned businesses, as well as illegal extraction of natural resources, including timber and fish (Lemos and Ribeiro, 2007; Lyman, 2006; Sun et al., 2017). Chinese firms and projects have also been accused of poor or unsafe working conditions, low wages, abuse, and exploitative practices (IHLO, 2006; McGreal, 2007; Tang, 2016). ${ }^{15}$ Finally, while portrayals of China's engagement across the continent are often negative or highly critical, many studies and public opinion surveys have suggested that Africans' attitudes.

About China are variegated, complex, and often positive (Afrobarometer, 2016; 2020; 2021; Dollar, 2016; Pew Research Center, 2019; Rebol, 2010; Sautman and Hairong, 2009). Notably, during the COVID-19 pandemic, anti-Chinese maltreatment and discrimination broke out in many African countries, which were mirrored by anti-African sentiment, discrimination, racism, and harassment in parts of China (Asiedu and Kazeem, 2020; HRW, 2020). Overall, although there has been considerable coverage and extensive study of China's engagement across Africa, increasing understanding of this important topic, to date there have been no studies exploring relations between China and Eritrea. The present study thus helps to fill the void, providing a broad review of China's engagement in Eritrea and also offering insight into locals' general perceptions of the relationship and about China more generally. In the following section, an overview of the methods is presented.

\section{Method}

The present study relied on a variety of methods. Data were collected through a comprehensive review of the general literature and an examination of numerous materials collected from an assortment of sources (e.g., regional or global institutions, non-governmental organizations, government offices and ministries, etc.), public open-access databases, and various secondary data sources (Snyder, 2019; Vartanian, 2011). Some of 
the documents and materials examined include books, datasets, general reports and reviews, websites, newsletters and newspapers, press releases or statements, government publications, and countless articles in leading academic journals available from electronic academic databases (e.g., EBSCO, Lexis-Nexis, JSTOR, etc.) or general online searches (to ensure breadth and include relevant information, resources, and knowledge not always indexed in academic databases). As well, between August 2018 and June 2021, in-depth, semistructured interviews were conducted with key informants from across the country. Key informants, selected through convenience and snowball sampling techniques, were from educational institutions, various ministries, and local and international organizations or businesses, and possessed first-hand knowledge and experience, deep understanding, and key insights about different aspects of China-Eritrea history and engagement. The wide array of sources helps provide a diversity of views and perspectives, ultimately broadening and enriching understanding of the topic (Flick, 2018).

In-depth, semi-structured interviews are effective in providing rich data and particularly useful since the research topic under investigation retained many exploratory features. Furthermore, open-ended questions offered respondents an opportunity to organize responses within their framework, thus potentially increasing the validity of responses and promoting understanding. While the interviews and questions were semi-structured, they involved many follow-up queries and creative locutions (such as, "why" and "what else") to further probe issues of merit or pursue clarity (Hammer and Wildavsky, 1989; Morris, 2015). All interviews began after obtaining verbal consent and were generally conducted in person or by telephone. Conversations lasted between one and two hours and were conducted in either Tigrinya or English (which are two of Eritrea's three national working languages). During all interviews, handwritten notes were taken, with transcription conducted shortly afterward, often the same day, to reduce errors and ensure a high degree of accuracy and detail (Newing, 2011). Additionally, utilizing anonymous survey questionnaires, data was collected from 237 students (mean age 21.83, SD 2.74) from a large college in Eritrea. Students were selected randomly from an enrolment list provided by the college and written consent was obtained from all respondents before distribution. The questionnaire was guided and informed by past surveys conducted by Afrobarobeter.

A non-partisan, pan-African research institution that has carried out numerous public attitude surveys on a range of topics in many African countries, including local perceptions about China (Afrobarometer, 2016; 2020; 2021). Inter alia, the questionnaire covered demographic characteristics, as well as explored respondents' general perceptions about China and its engagement in the country. Finally, the paper is also guided by numerous informal conversations and several focus group discussions. Notably, focus groups are practical and effective as they can reveal "how several people work out a common view or the range of views, about some topic" (Fielding, 1993: 141). Moreover, the utilization of focus groups helps to stimulate fruitful discussion and bring to the surface locals' responses and perspectives about China that otherwise might lay dormant. For example, participants, based on engaging with others, may be able to articulate more clearly their thoughts or views than they otherwise might if alone (Babbie, 2007: 308). Data analysis is based on data triangulation: obtaining, comparing, and contrasting evidence from a wide range of data sources. Relying on multiple sources of data allows for the convergence of various lines of inquiry and strengthens validity (Bieri, 2010; Creswell and Miller, 2000: 126; Yin, 2003), and is important in gaining cumulative insights and acquiring a broader, richer perspective of China-Eritrea engagement.

\section{Results and Discussion}

General Background: After waging one of Africa's longest and most destructive liberation wars of the 1900s, Eritrea won its independence in 1991 (de jure in 1993). Possessing a long coast on the Red Sea, the country shares land borders with Djibouti, Ethiopia, and Sudan. Eritrea has an area of approximately 117,600 square kilometers and is divided into six main political administrative regions (locally called "zobas", these individually vary in terms of size, population, and socio-economic conditions). The population of Eritrea is approximately 3.5 million, which is distributed between nine separate ethnolinguistic groups and split almost evenly between Christianity and Islam (with each representing nearly half of the population). Eritrea's percapita gross domestic product (GDP) is approximately US\$626 (at current prices), while the economy is largely based on subsistence rainfed agriculture and pastoralism. These sectors constitute between onequarter and one-third of GDP, although in recent years, mining copper, gold, iron ore, nickel, silica, sulfur, 
marble, granite, potash, and tin) has emerged as an increasingly significant sector (AfDB, 2021b; IFAD, 2021; IMF, 2021; World Bank, 2021b). (Image 1 Here)

Despite its relatively modest resources, Eritrea is one of the few countries that entered the UN Sustainable Development Goals period having achieved most of the UN Millennium Development Goals targets related to health (Ministry of Health and UNDP, 2014; Pose and Samuels, 2011; UN Eritrea, 2017; WHO, 2018). At the same time, although these developments reflect considerable progress and improvements, the country continues to be confronted by a myriad of significant issues, including regional conflict and instability, an extended period under international sanctions; poverty reduction, socio-political challenges, emigration, climatic shocks, erratic rainfall and the potential for severe, recurrent drought, infrastructure development, food and nutrition insecurity; a shortage of skilled labor; and macroeconomic imbalances (AfDB, 2021b; IFAD, 2021; Ministry of Health and UNDP, 2014; Pose and Samuels, 2011; UN Eritrea, 2017; World Bank, 2021b).

Historical Overview: China's relationship with Eritrea is not a new or recent one; it stretches back almost 2,000 years, to as early as about $100 \mathrm{AD}$, involving maritime trade and commercial activities, as well as the dispatch of emissaries (Bing and Dashu, 2018; Li, 2005; 2012). ${ }^{16}$ However, contemporary ties can be traced back to Eritrea's long struggle for independence from Ethiopia. China gave a small load of rifles to the Eritrean Liberation Front (ELF) in 1966; while a small number of Eritrean independence fighters were also sent to study and train in China. ${ }^{17}$ The earliest group of fighters sent to China included Isaias Afwerki, a key figure throughout the country's independence struggle and the country's current president. Having successfully navigated a long revolutionary struggle, China was also a source of useful insights, ideas, lessons, and encouragement for the growing independence movement in Eritrea. For example, the fighters drew insights and lessons from Chairman Mao's principles of guerrilla warfare and peasant-based social revolution.

As well, translations of Maoist texts reflected an adaptation of the tactics and strategies of the "People's War", while "criticism and self-criticism" sessions became an integral feature of units within the Eritrean People's Liberation Front (EPLF) (Iyob, 1997: 659). China's initial benevolence towards the Eritrean independence fighters was intended to exert pressure on Ethiopia, ruled by Emperor Haile Selassie, to diplomatically recognize the PRC and cease its opposition to China's admission to the UN. When these aims were eventually attained in 1970, the PRC quickly shifted to strengthening its relations with Ethiopia and rejecting further aid or support to the Eritreans (Markakis, 1988). After overthrowing Emperor Haile Selassie in September 1974, the Derg, Ethiopia's left-wing military junta, dispatched missions across the world, including to China, to stress the revolutionary character of the new regime, while at the same time branding Eritrea's independence movement as anti-progressive and reactionary. In 1976, China also sent 200 tons of light arms to the Ethiopian regime, which was preparing for a military solution to the longstanding Eritrea question (Ottaway and Ottaway, 1978: 176).

China's abandonment of Eritrea's cause and general support for Ethiopia (notwithstanding a strained relationship due to ideological differences and Ethiopia's close relationship to the USSR) meant that Eritreans no longer regarded them as a genuine ally or credible partner. ${ }^{18}$ Relations between China and Eritrea would eventually recommence upon Eritrea's independence. The two countries established diplomatic relations on May 24, 1993, and China quickly opened an official embassy in the newly independent country. Months later, in September, Isaias Afewerki, the President of Eritrea, met with China's Minister of Foreign Affairs at the $48^{\text {th }}$ UN conference. China and Eritrea also signed a deal on trade, economic, and technological cooperation, with China also agreeing to provide some military aid. Subsequently, in 1994, China extended a US\$4.3 million interest-free loan to Eritrea, which in the aftermath of a long, extremely devastating war, was confronted by a massive need for reconstruction. Since then, Chinese engagement with Eritrea has steadily increased, extending into many different areas and sectors.

Health and Education: Among the most extensive and important areas of Chinese involvement in Eritrea have been the health and education sectors. Regarding the former, China helped to build and upgrade Eritrea's largest medical facility, the Orotta Hospital, which is located in the capital, Asmara. Opened in 2003 following three years of construction, the country's first fully-equipped, modern hospital was financed through a US $\$ 10$ million interest-free loan from the Chinese government. Subsequently, China has also extended support for regular upgrades and expansions. In 2009, Eritrea's Ministry of Health and the Chinese 
International Trade Engineering Design and Research Institute signed an agreement to construct a heart surgery room, physiotherapy and oxygen production facilities at the hospital, as well as to develop an underground pond with a capacity of 500 cubic meters of water and repair water pipelines and other facilities. In 2014, new cardiac and neurology facilities, worth approximately US\$5 million, were also added. Furthermore, since 1997, well over 200 Chinese doctors and health professionals have provided free medical services and training (including on Chinese traditional medical practices) in the country. China has also donated significant amounts of medical equipment and medicines.

While a Chinese company built a pharmaceutical plant in Keren in 2003. Regarding education, China has supported the building and renovation of schools and universities across Eritrea. In 2010, a large college, located in Adi Keih, in the south of the country, was opened, with the Chinese government donating over US\$10 million toward its construction. Another college, located near Asmara, was opened in 2017. Construction of the US $\$ 25$ million projects, the largest ever Chinese aid package in the country, was led by the Chinese Civil Engineering Construction Corporation. That year also saw yet another college, north of the capital, constructed by a Chinese company. Alongside its support for developing institutions of higher learning, China has contributed to the building of elementary schools across the country, including the Erafaile Elementary School in Asmara, which was built at a cost of US\$4 million and opened in 2014. Importantly, China has provided Eritreans with government-funded scholarships to study or train in China, as well as organized numerous training programs and exchanges for ministries, organizations, and public enterprises. The Chinese Embassy in Eritrea, too, has offered courses and workshops for locals. Finally, China has donated a substantial amount of educational resources, such as books, computers, printers, stationary materials, and other supplies.

Through its considerable and variegated assistance, China has played a positive, supportive role in some of the significant improvements in health and education in Eritrea. Notably, a large body of work from various settings around the world has demonstrated that improved, modernized, and better-equipped health facilities can raise the standard of care, strengthen health capacity, and promote positive outcomes (CGD, 2015; Datar, Mukherji, and Sood, 2007; Marrufob, 2007; WHO, OECD, and World Bank, 2018). Similarly, the construction of schools, improvement of infrastructure, and expansion of resources or learning materials can raise access and enrich educational experiences (Ahiakpor, Nunoo, and Alnaa, 2014; Glewwe and Jacoby, 1994; Handa, 2002; Lavy, 1996). Around two-thirds of the country's population lives in rural areas, with farming, animal herding, and fishing being the mainstay of livelihoods for a large percentage of the population. What is more, China's assistance to these sectors has augmented Eritrea's own efforts to strengthen its human capital development, which numerous empirical studies have often shown to be vital to socio-economic growth, productivity, and development (Bleakley, 2010; Haldar and Mallik, 2010; Krueger and Lindhal, 2001; Sweetland, 1996), while Chinese assistance to ministries and public enterprises helps improve productivity and efficiency.

Agriculture: Another area of considerable Chinese assistance to Eritrea has been agriculture. The Eritrean economy is largely based on subsistence agriculture and pastoralism, which constitutes approximately onequarter and one-third of GDP. However, food security, low productivity, and archaic farming practices are significant challenges (AfDB, 2021b; IFAD, 2021; IMF, 2021; World Bank, 2021b). Within this context, Chinese cooperation has been important. In 1994, shortly after its formal independence, Eritrea borrowed US $\$ 3$ million from China to purchase Chinese agricultural machinery. The debt was eventually canceled in 2003, as China extended Eritrea a grant for the same amount. During that year, which saw a regional draught, Eritrea also received 2000 metric tons of maize donated by the Chinese government. In 2010, China extended a US\$6 million interest-free loan to Eritrea for food security development, while in July 2013, the Shanghai Corporation for Foreign Economic and Technological Cooperation (SFECO) began work on several agriculture-related projects: three cold food-storage facilities.

An aluminum-can manufacturing plant and a high-quality PVC drip-irrigation pipe production line. The projects were financed via a preferential loan of US\$103 million to Eritrea from the Chinese government. As well, the Xinjiang Autonomous Region of China donated a solar power drip-irrigation project to Eritrea, which was completed by China's Tianye Company in 2015. Notably, a number of Chinese agricultural experts, in cooperation with national ministries and institutions in Eritrea, have regularly organized training workshops 
in the country to promote modern cultivation techniques and improve productivity. China's assistance to Eritrea's agricultural sector has been important and useful, as it has helped it to overcome many constraints. In particular, Chinese support has aided the expansion of irrigation and improvement of productivity and food security, as well as contributed to the raising of incomes, poverty reduction, and economic growth. What is more, modernization and progress in the sector can help Eritrea to reduce its heavy dependence on the extractive sector as the main driver of the country's economic growth.

Infrastructure: Decades of war led to massive destruction in Eritrea, with buildings, roads, schools, and other structures destroyed. Against this backdrop, Chinese assistance and financing have been instrumental in addressing the country's massive infrastructure deficit. In 2005 and 2006, China's Export-Import Bank granted Eritrea loans of US $\$ 21.45$ and US $\$ 23$ million, respectively, to build infrastructure for fixed and mobile telephones and to improve the national telecommunications network. The projects, involving Zhongxing Technologies, a Chinese state-owned company, established and renovated facilities, greatly expanding network coverage, while China has also regularly donated communications equipment and technology. Additionally, in recent years China has made some contributions to Eritrea's efforts to develop its radio and television broadcasting capacity through donating equipment, offering several scholarships, organizing training programs and workshops, and making films and television programs available. China has also supported power generation in Eritrea, an area that has historically been insufficient. In 2018, a solar plant project was completed, financed by grants from the Chinese government, while in November 2017, a US\$99 million project to upgrade and expand Eritrea's largest power plant, Hirgigo, located in Massawa, on the country's long Red Sea coast, was completed. Financing for the two-year project was provided by China's Export-Import Bank and construction work was contracted to SFECO.

Which implemented the project in close cooperation with the Eritrean Electric Corporation? The project added two 23-MW oil-fired power generators, supplied under contract by China-based Qingdaohaixi Marine Diesel, to the power plant, increasing the country's installed power capacity by about 60 percent. Another Chinese company, Shanghai Bluestar Cleaning Company, completed a US $\$ 130,000$ contract to restore the power station's water desalination plant, where heavy scaling adversely affected the quality and output of water used for electricity generation. Additionally, in 2011, the Gedem Cement Plant was completed. Its establishment was financed by Chinese preferential loans totaling US $\$ 108$ million, and the project was implemented by the China New Era International Engineering Corporation. Like it has done in other parts of Africa, China has helped construct roads in Eritrea. In the mid-1990s and early 2000s, several major roads projects were completed in Massawa and Asmara, with the works being led by China's Sichuan Road and Bridge Mining Company (SRBM). More recently, in early 2018, China extended a US $\$ 87$ million loan to Eritrea for the construction of the 29km first phase of the Adi Guadad - Habela - Agordat road. China's support for infrastructure development in Eritrea is important for raising living standards, spurring growth, promoting poverty reduction, and improving socio-economic development. For example, while Eritrea's telecommunications network is still relatively underdeveloped, it has expanded substantially.

The number of mobile users has dramatically increased and mobile phones are now widely used in many parts of the country (including in rural areas and on islands), while access to internet services has also grown. The Gedem Cement Plant, which has supplied cement locally and to surrounding countries, created jobs for hundreds of locals, while the expansion of Hirgigo improved power generation and significantly reduced frequent and costly halts for maintenance. Improved electrical supply lowers costs for users, encourages private sector development, and increases productivity among both households and businesses. ${ }^{19}$ Finally, developing road and port infrastructure helps address the significant costs and delays faced by exporters and importers while helping Eritrea to better capitalize on its strategic location.

Economy: China has become an increasingly important trade and economic partner to Eritrea. At present, it is the country's main investor, creditor, and trading partner. Along with the assistance and projects detailed above, from 2002 to 2004 China extended Eritrea several grants, worth a total of US\$6 million, for use in economic and technical sectors. Regarding trade, China is the principal destination of Eritrea's exports and has remained among the leading sources of Eritrea's imports (behind the United Arab Emirates and Egypt). Total trade between the two countries increased from less than US\$1 million in 1994 to US\$8.24 million in 2005 , nearly US $\$ 40$ million in 2010 , and was approximately US\$360 million in 2020. In January 2007 , China 
and Eritrea signed economic deals, which included the removal of tariffs on Eritrean products imported to China and the partial cancellation of Eritrea's debt to China. (Figure 5 Here)

Worth keeping in mind, however, is that although the volume of trade between the two countries has considerably increased, it still represents only a minuscule share of China's total trade on the continent and lags far behind some of the annual volume figures of China's trade with countries in the region. For instance, in 2020 the volume of China-Africa trade was about US $\$ 187$ billion (China State Council, 2021; UN Comtrade, 2022). Trade between China and Eritrea tends to follow the general pattern of other countries in Africa. Eritrea mainly exports natural resources (e.g., copper and zinc), while Chinese exports to Eritrea consist of industrial machinery and equipment, as well as finished products. China has been the main customer for copper from Eritrea's Bisha mine since copper production began in 2013. Eritrean exports to China rocketed from US\$1.26 million in 2012 to US\$50.93 million in 2013 and were about US\$289 million in 2020. Eritrea's extractive sector is one of the country's most vital, and nearly 20 international companies from around the world are involved in projects at various stages of development. Similar to its engagement in many other African countries, China has been especially active within Eritrea's extractive sector.

Eritrea has two operational mines. Bisha, the first significant mine in Eritrea for over 75 years and the country's first major international investment, produces gold, copper, and zinc. It was originally a jointventure between the state-owned Eritrean National Mining Corporation (ENAMCO), which now holds a 45 percent interest, and the Canadian company Nevsun Resources Ltd. (55 percent), before the latter was acquired by China's state-backed Zijin Mining Group Company in 2018. ${ }^{20}$ In 2007, the China Export-Import Bank provided Eritrea with a US\$60 million soft-loan to help finance its purchase of an initial 40 percent stake in the Bisha mine. Eritrea's other operational mine, the Zara gold mine, is owned by ENAMCO (40 percent) and SFECO (60 percent), with the mine's two-year engineering, procurement, and construction project, worth US\$84 million, having been undertaken by SFECO. Another mine, the Asmara Project, is expected to commence production in the near future, is owned by ENAMCO ( 40 percent) and China's SRBM (60 percent), while numerous other Chinese exploration and surveying companies are also active in the country. The mining sector, within which China has been highly active and supportive.

Has been Eritrea's primary source of income and economic growth. For years, the Bisha mine has remained Eritrea's single most productive economic asset, contributing to about 8-10 percent of the country's total GDP and providing over US $\$ 1$ billion in revenues since it began commercial production in 2011. As well, mining companies have made significant payments for local goods and services, while Eritrean companies have earned money for constructing infrastructure for the mines (e.g., roads and staff accommodations). For example, in 2011, Nevsun spent US\$43.2 million on purchases of fuel, heavy mobile equipment, construction materials and other goods and services from Eritrean vendors. Millions are also received every year in the form of taxation, royalties, and various fees. Doubtless, revenues from the mining sector have helped to lighten the country's debt burden and provided much-needed foreign exchange, which is in short supply. (Figure 6 Here)

In terms of FDI, China is the leading investment country of origin for Eritrea; from 1994 to 2019, the total Chinese investment in Eritrea was about US $\$ 400$ million. As well, China's FDI stock in Eritrea, largely driven by mineral resources, increased from about US $\$ 1.9$ million in 2003 to about US $\$ 379$ million in 2016, before dropping to about US\$224 million in 2019. (In contrast, there is no direct Eritrean investment flow to China.) While this growth is significant, the figures are considerably smaller than China's FDI stock in other African countries. For instance, the total FDI stock in Africa in 2019 was about US $\$ 44.4$ billion. Of note, Chinese firms have dominated contracts to upgrade infrastructure in the country, and in 2012 SFECO won a contract worth US\$162 million from the Eritrean government to deliver heavy industrial machinery, transport equipment, and spare parts (e.g., buses, tractors, cranes, etc.). Between 1998 and 2019, annual gross revenues for Chinese construction companies working in Eritrea have ranged from about US\$3 million to US\$366 million. (Figure 7 and Figure 8 Here)

An interesting aspect of Chinese economic activity in Eritrea is that unlike in many other countries across the continent, the number of Chinese workers active in Eritrea has remained limited. While this is partly down to China's relatively low level of involvement in Eritrea compared to other countries in Africa, it is also a result 
of Eritrea's policies regarding foreign workers. Specifically, Eritrea has strict national regulations about foreign workers, with companies having to first offer positions to locals and also to demonstrate that there are no suitable or qualified local candidates. There are also strong regulations in place about training locals and knowledge or skills transfer. Notably, in November 2021, Eritrea signed a memorandum of understanding to join China's BRI. Not long after, during the first week of January 2022, Wang Yi, State Councilor and Foreign Minister of China traveled to Asmara, where he met with his counterpart, Foreign Minister Osman Saleh, and President Isaias. The two foreign ministers also signed a joint statement laying out plans for further cooperation, and the relationship between the two countries was elevated to the level of "Strategic Partnership" (among the highest designations within China's hierarchical categorization of foreign partnerships), thus signaling a further consolidation of their relationship. China also extended \$US16 million to Eritrea in assistance (Shabait, 2022a; 2022b). ${ }^{21}$

International Relations: Among the central planks underlying the longstanding relationship between Eritrea and China has been their firm commitment to the principle of mutual respect. This is just one part of their shared broader views of international relations and the global system. In particular, along with mutual respect, both states emphasize sovereignty, non-intervention, and non-interference in internal affairs. Both also believe in the centrality of multilateralism and the UN-centered international system, generally agree on a wide range of international issues, and share similar views and approaches to global organizations and human rights. For instance, China and Eritrea have called for changes to the framework and functioning of the UN (FMPRC, 2005; Shabait, 2016a), and even participated in initiatives to reform its structure or processes. In July 2021, for instance, the two joined a group of nearly 20 countries to establish the "Group of Friends in Defense of the Charter of the United Nations" at the UN (Group of Friends, 2021). As well, both countries have opted into the international human rights framework by signing up to many international and regional human rights treaties. At the same time, China and Eritrea have challenged the often dominant Westerncentric view of human rights and expressed reservations or concern about perceived Western control over the human rights agenda (China State Council, 2016; 2019; Chen, 2019; Shabait, 2015; 2016b; 2018).

For China, Eritrea is a source, albeit a relatively modest one compared to some of its other partners, of natural resources. It also holds significant untapped potential, represents a credible, reliable partner, and offers a fairly easy, stable environment. China's growing ties with Eritrea not only provide it a gateway to the continent and help integrate its links across the region (China has invested heavily and maintains significant economic interests in neighboring Ethiopia, South Sudan, and Sudan); it also strengthens its foothold in a vital geostrategic area and along critical transit routes for global trade. The Bab el-Mandeb Strait forms a vital link in the maritime route between the Mediterranean Sea and the Indian Ocean via the Red Sea and the Suez Canal. The rapidly rising significance of the region for Chinese foreign policy is evidenced clearly in the fact that its first overseas military base was recently established in the Horn of Africa (Djibouti), while in January 2022 it also announced it would assign a "special envoy" for the region (Miriri, 2022). On the other hand, beyond the various socio-economic and development benefits that it accrues (including the potential to become an important regional hub); Eritrea is drawn to working with China because doing so comes with no overbearing provisions or stipulations of conditions.

This allows Eritrea to maintain its independence and retain autonomy and ownership of its development path and policies. Although Eritrea has been criticized by some Western countries for its internal policies and rights record, China has not pressured it or interfered in its domestic affairs. As a part of their diplomatic relationship, and likely since they have experienced similar criticisms, China and Eritrea have frequently extended each other moral and political backing within international fora. For instance, since the establishment of diplomatic relations between the two countries, Eritrea has consistently reaffirmed its support for the "One-China Principle", while also backing China within international human rights bodies. At the $44^{\text {th }}$ session of the UN Human Rights Council in mid-2020, Eritrea was part of a group of 53 countries that released a statement backing China's Hong Kong Security Law, under its right to enact legislation. Also, in July 2019, Eritrea was a signatory, along with 36 other countries, to a letter to the UN Human Rights Council praising Beijing's, "remarkable achievements in the field of human rights" (Xinhua, 2019), while during the 2014 UN Universal Periodic Review (UPR) Eritrea congratulated China on, "its efforts to discharge its obligations in the promotion and protection of basic human rights" (UN HRC, 2014). China, for its part, has reciprocated. At the UN Human Rights Council in 2019, in the face of Western pressure, China explained that 
as a young, developing country Eritrea faces many challenges and the international community should bear this in mind to provide a fair, objective, and comprehensive view of the human rights situation in the country (OHCHR, 2019).

Additionally, during a 2016 hearing on human rights in Eritrea, as some Western countries criticized Eritrea's rights record, China instead reiterated its opposition to country-specific mandates, thus aligning with Eritrea's position, and praised the country for making "steady progress in human rights in recent years, with particularly remarkable results in economic, social and cultural rights" (China Mission, 2016). Notably, for years Eritrea was saddled by UN Security Council sanctions and attempts at regional and international isolation, led by the US and previous Ethiopian governments. ${ }^{22}$ Although China did not veto the UN resolutions to sanction or maintain annual monitoring procedures on Eritrea (and also adhered to the arms embargo placed on the country), it was one of the few countries that continued to invest in, trade with and engage Eritrea. This filled an important void and provided critical support to Eritrea. Perhaps because it was itself a country that was often on the receiving end of international sanctions and rebukes, China also frequently expressed moral backing for Eritrea's stance or voiced concern about the procedures taken against it within international fora. Doubtless, China's approach during the period was influenced by the fact that it needed to balance its support for Eritrea with its own much closer and considerably larger economic relationship with Ethiopia, Eritrea's vastly more populous neighbor and rival. (Eritrea and Ethiopia peaceful resolved their conflict in 2018 and are now close allies.) More recently, China has repeatedly criticized and more forcefully objected to the imposition of unilateral sanctions on Eritrea by the US, regarding them as "illicit" and "groundless under international law" (FMPRC, 2021; Shabait, 2022a).

Local Opinions: Overall, survey results indicate that Eritreans generally view China and its engagement with the country quite favorably. In response to a question about China's influence on the world, 61 percent of respondents saw it as having a "positive" or "very positive influence," while 19 percent saw it as having a "negative" or "very negative" influence. When asked whether China's influence on Eritrea, specifically, was positive or negative, 70 percent of respondents regarded it as "somewhat positive" or "very positive," with 12 percent seeing it as "somewhat negative" or "very negative." Notably, this is in alignment with other works exploring Africans' perceptions about China. For instance, in the most recent series of Afrobarometer national surveys, which polled nearly 50,000 respondents in 34 African countries between the years 2019 and 2021, almost two-thirds (63 percent) of respondents felt the influence of China in their country was "somewhat positive" or "very positive," while only about one in seven (14 percent) considered it "negative" (Afrobarometer, 2021).

Additionally, recent examinations of global views of China, conducted by the Pew Research Center, found that 70 percent of Nigerians and 63 percent of Tunisians held favorable opinions about China (Pew Research Center, 2019). Many other works have had similar results (Afrobarometer, 2016; 2020; Dollar, 2016; Rebol, 2010; Sautman and Hairong, 2009). A longstanding controversy surrounding Chinese engagement in Africa has been about its effectiveness and also whether it may lead to the loss of local jobs or displacement of local businesses. When asked to consider how helpful Chinese assistance is in Eritrea, a majority of respondents (64 percent) said it was "very helpful" or "somewhat helpful," with 13 percent responding that it was "somewhat or "very unhelpful." The majority of respondents (71 percent) were "somewhat satisfied" or "highly satisfied" with Chinese-supported infrastructure projects in the country, with 15 percent of respondents "somewhat or highly dissatisfied." These particular findings may be attributable to the fact that large projects, such as hospitals, schools, and roads, are highly visible and easily recognized, as well as the fact that many people directly benefit from them.

In addition, 62 percent of respondents "agreed" or "strongly agreed" with the statement, "Chinese companies and investment create employment opportunities," with 21 percent "disagreeing" or "strongly disagreeing." By comparison, a Pew 2019 survey in Nigeria found that a sizable majority of Nigerians, 82 percent, said Chinese investment is a good thing because it creates jobs in their country (Pew Research Center, 2019). While Eritrea has experienced extended periods under sanctions and been on the end of efforts at isolation, China continued to engage with and invest in the country, supporting socio-economic growth and helping keep the economy afloat. It is also important to note that the number of Chinese workers in Eritrea has remained limited, with strict labor regulations stipulating the hiring and training of locals. Thus, increased 
Chinese involvement does not directly threaten local jobs or businesses. Interestingly, while results indicate that Eritreans hold overall positive perceptions of China.

There were negative views about Chinese products. 71 percent of respondents "disagreed" or "strongly disagreed" with the statement, "Chinese companies offer products and services of high quality," with only 18 percent agreeing or strongly agreeing. This is consistent with surveys conducted in other settings. For example, in Afrobarometer's 2014/2015 surveys in 36 countries across the continent, more than one-third (35 percent) of Africans said that the poor quality of Chinese products damages China's image (Afrobarometer, 2016). Also, in a survey of over 1,000 respondents across 15 African countries, 68 percent "disagreed" or "strongly disagreed" with the statement that, "Chinese products and services are of high quality" (Geerts, Xinwa, and Rossouw, 2014). During interviews and discussions with Eritrean respondents, many claimed that products "didn't last long" or "performed poorly." However, it was also frequently pointed out that the availability of Chinese products was quite important because they provided many Eritreans with access to goods and amenities they otherwise would not be able to have (Table 1 Here).

\section{Conclusion and recommendations}

Although a large and growing body of literature has explored China's growing activities across Africa, the present study is the first to explore its engagement with Eritrea. Contemporary ties between China and Eritrea, which can be traced back decades, have considerably grown and intensified in recent years. China has become an increasingly important partner for Eritrea, and today it is the country's leading creditor, investor, and trade partner. Chinese assistance and cooperation across various sectors within Eritrea has helped support socio-economic growth and general development. While China's activities in Africa have been heavily scrutinized and garnered criticism, survey results indicated that young Eritreans hold largely positive, favorable perceptions of China and its engagement with their country. Notably, these findings generally align with results from other work exploring Africans' perceptions about China and its activities on the continent. For Eritrea, China's engagement is welcomed because it comes without conditions and allows it to maintain its independence and sovereignty, an issue of paramount importance for the country. Moreover, China has been a "reliable friend" to Eritrea, retaining and even strengthening its ties with the country, even as Eritrea has faced international sanctions, criticism of its internal policies, and efforts at isolation. On the other hand, China's engagement with Eritrea has served its interests and been driven by economic and geostrategic considerations.

Cooperation with Eritrea not only provides natural resources, but it also creates business opportunities for Chinese service contractors (e.g., construction companies), helps it link and integrate its interests in the region, offers another gateway to the rest of the continent, and allows it to strengthen its foothold in a vital geostrategic area. Furthermore, Eritrea unwaveringly expresses its backing for the "One-China Principle", fundamental bedrock of Chinese policymaking and diplomacy, and it also serves as a source of support within multilateral fora. As cooperation between China and Eritrea continues to evolve and appear set to deepen further, there is an abundance of possible avenues for further debate, research, and investigation. For instance, while surveys in the present study were cross-sectional and based on a sample of undergraduate students, future research could explore the views of a broader swath of the general population or adopt a longitudinal approach to consider possible shifts over time. Additionally, future work may examine specific, narrower dimensions of their relationship or examine how China's growing activity in the country or region influences local and regional peace, security, and stability. 


\section{Image 1: Eritrea Geographic Setting}

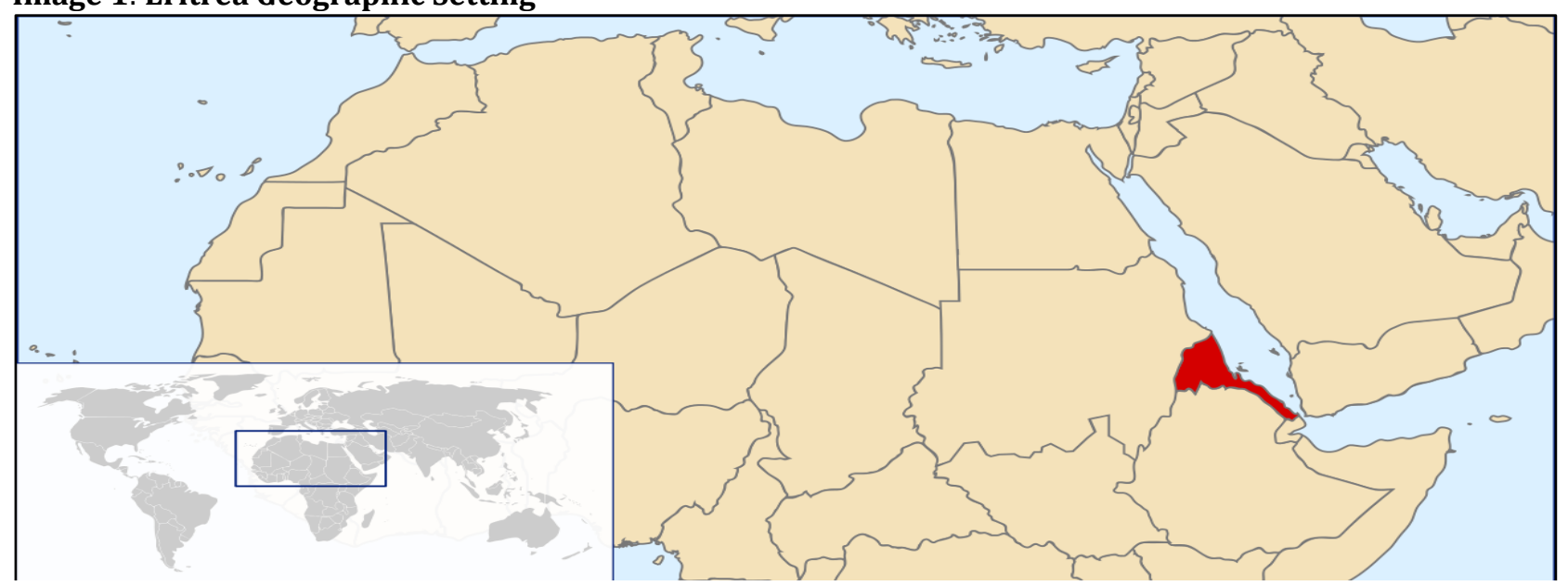

Image credit: https://commons.wikimedia.org/wiki/File:LocationEritrea.svg

Figure 1: China-Africa Exports and Imports, 1992-2020

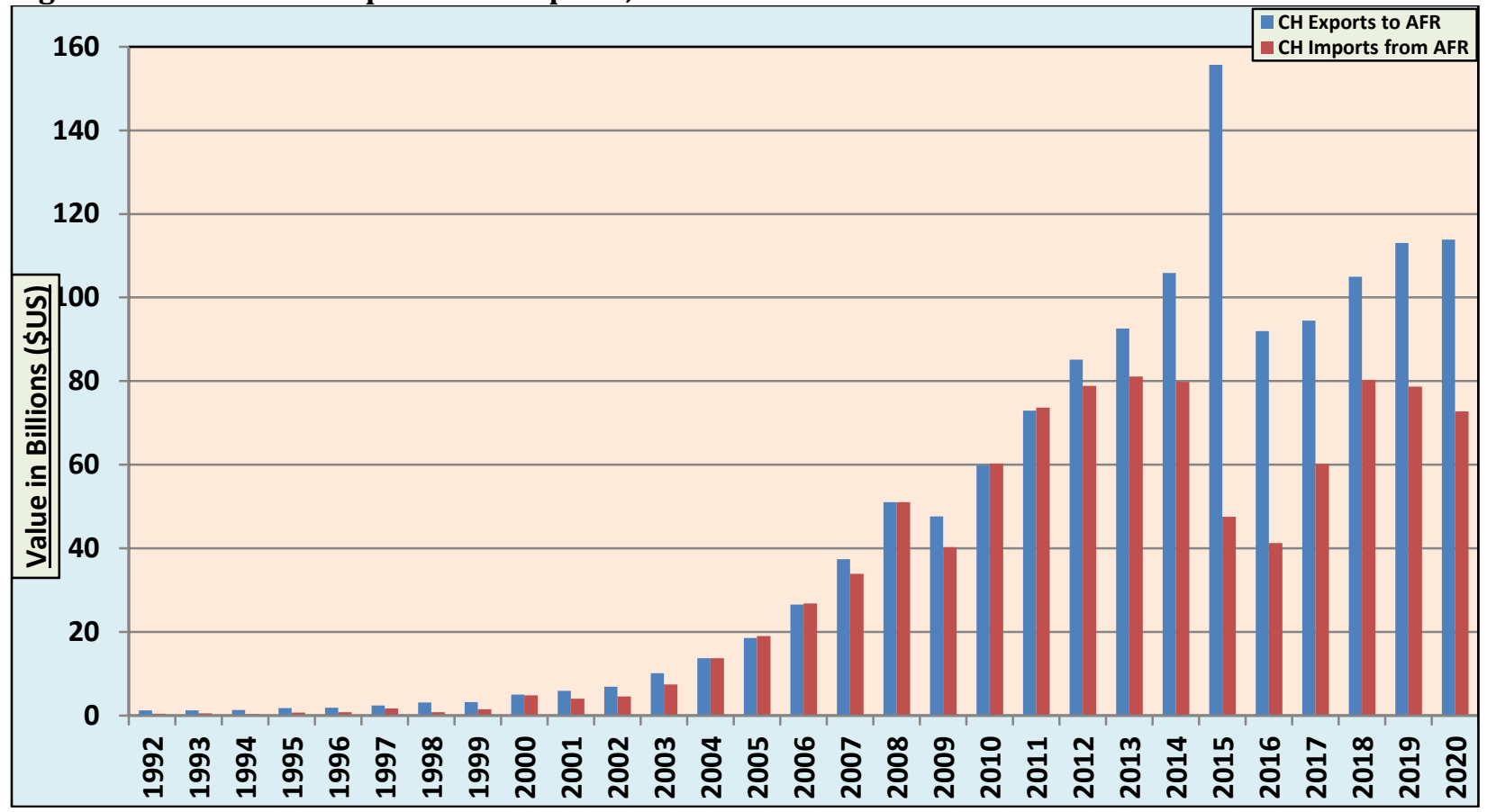

Data are retrieved from CARI (2022), which provides aggregated data on China-Africa trade from 1992 to 2019. (These data are from the UN Comtrade database.) The data for 2020 are retrieved directly from the UN Comtrade database (UN Comtrade, 2022). Although complete data for 2021 are unavailable, official Chinese sources show that for the period spanning January to September trade between Africa and China was about US $\$ 185.2$. This data is presented only as a total, rather than in terms of imports and exports (China State Council, 2021). Note that while UN Comtrade and Chinese government sources do not report the same trade figures, the two sources are very similar. 
Figure 2: China-Africa Total Trade Volume, 1992-2021

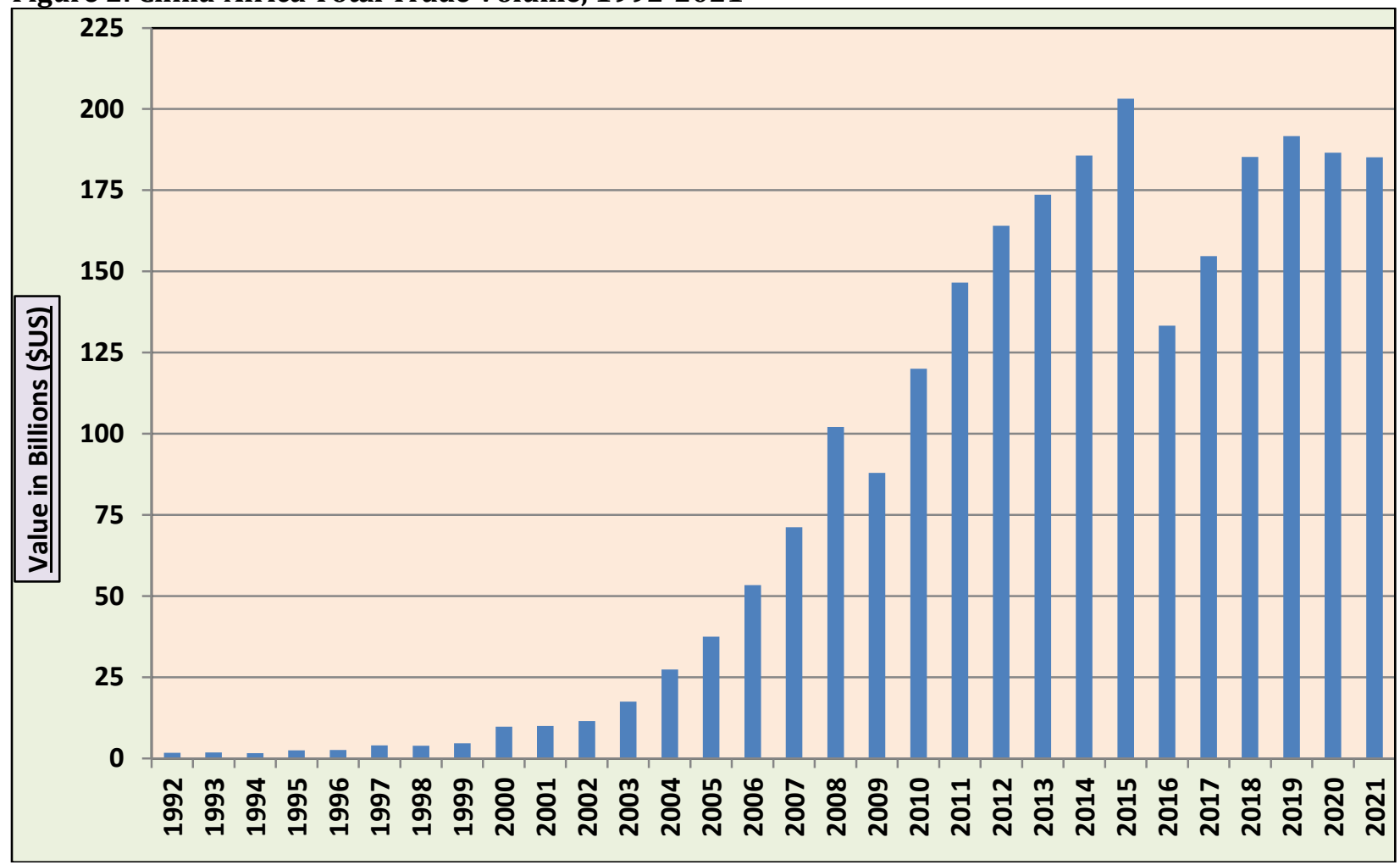

Data are retrieved from CARI (2022), which provides aggregated data on China-Africa trade from 1992 to 2019. (These data are from the UN Comtrade database.) The data for 2020 are retrieved directly from the UN Comtrade database (UN Comtrade, 2022). Although complete data for 2021 are unavailable, official Chinese sources show that for the period spanning January to September trade between Africa and China was about US $\$ 185.2$ (China State Council, 2021). Note that while UN Comtrade and Chinese government sources do not report the same trade figures, the two sources are very similar.

Figure 3: Chinese FDI Flow to African Countries, 2003-2020

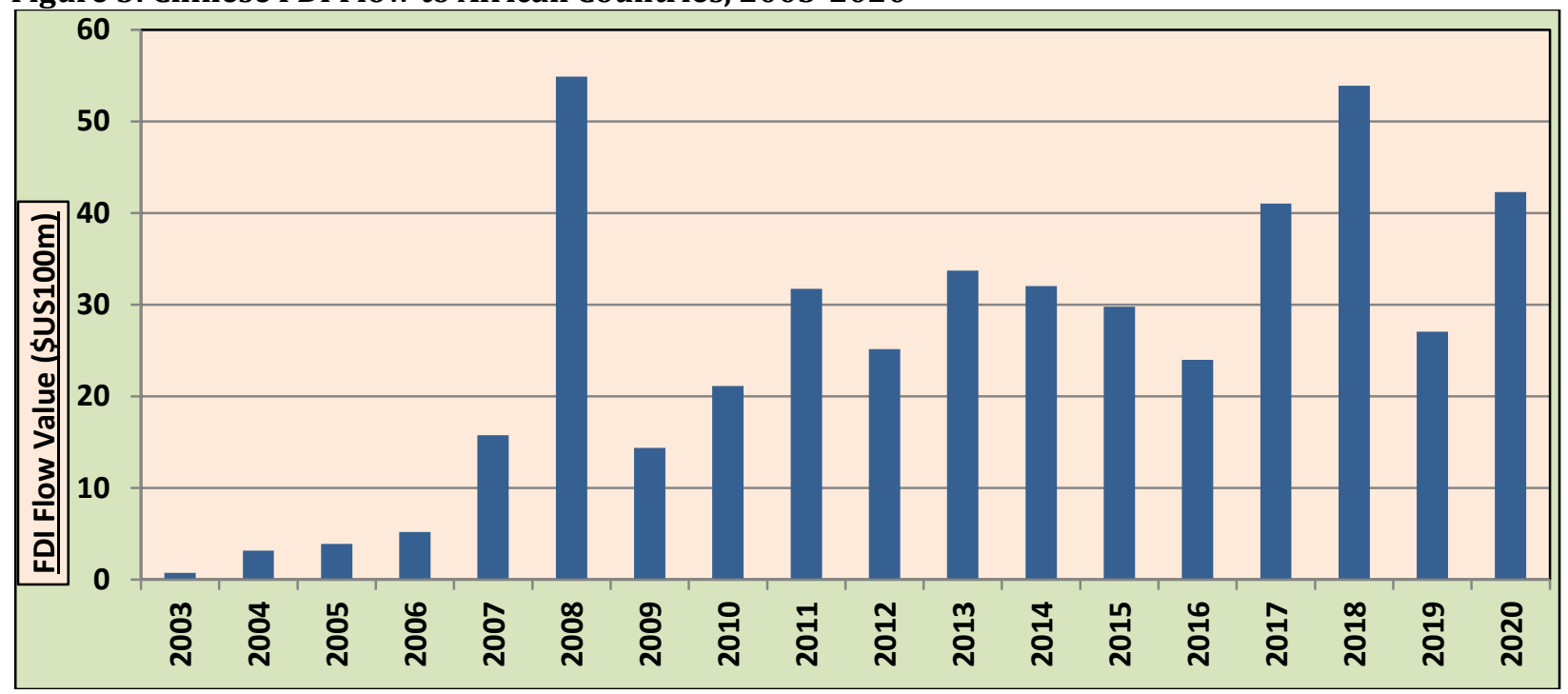

Data for 1992 to 2019 are retrieved from CARI (2022), while data for 2020 are from China State Council (2021). 
Figure 4: China Global Foreign Aid: Percentage of Total from 2013-2018 by Recipient

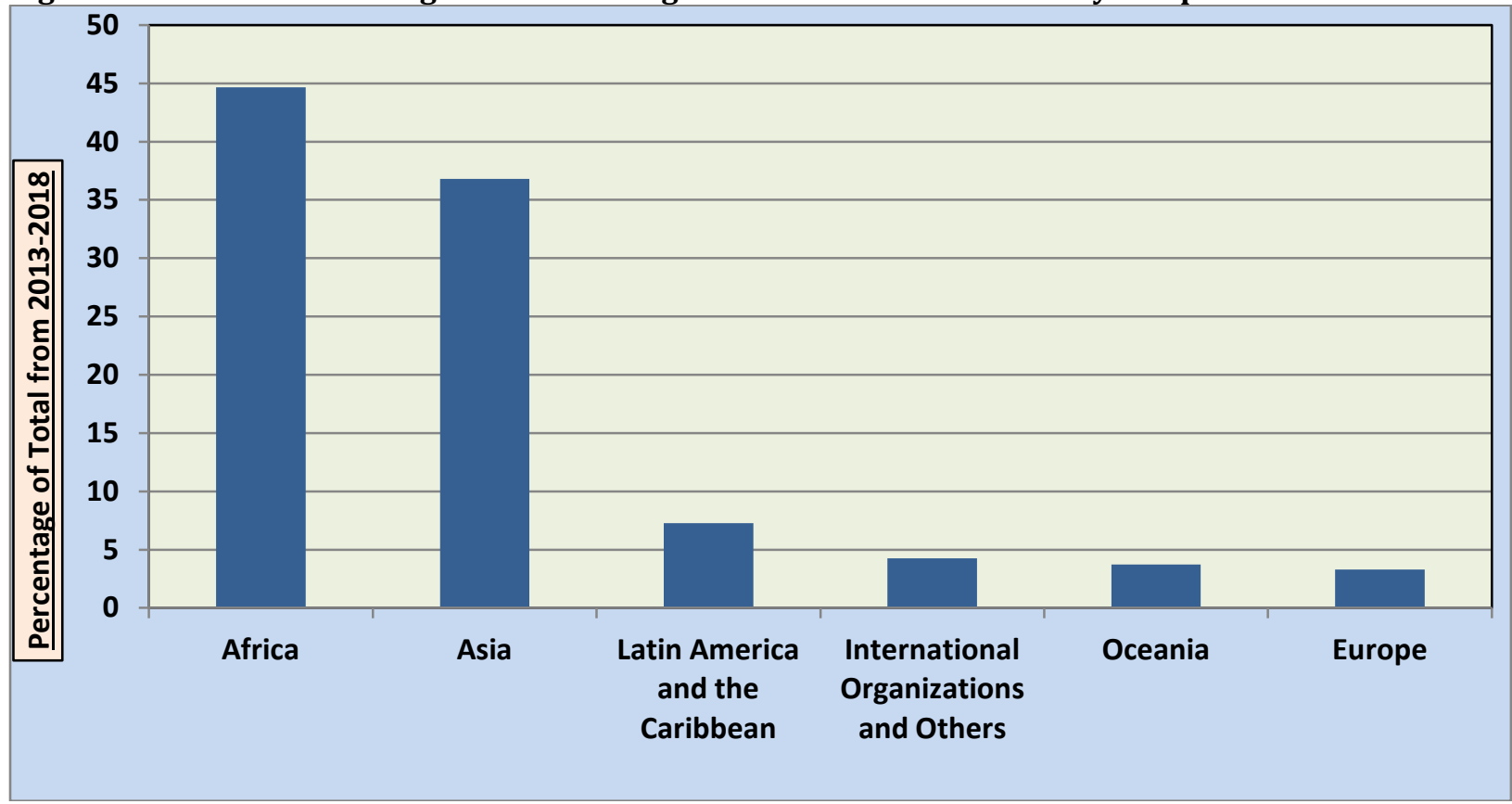

Data are retrieved from China State Council (2021).

Figure 5: Eritrea-China Total Trade, 1994-2020

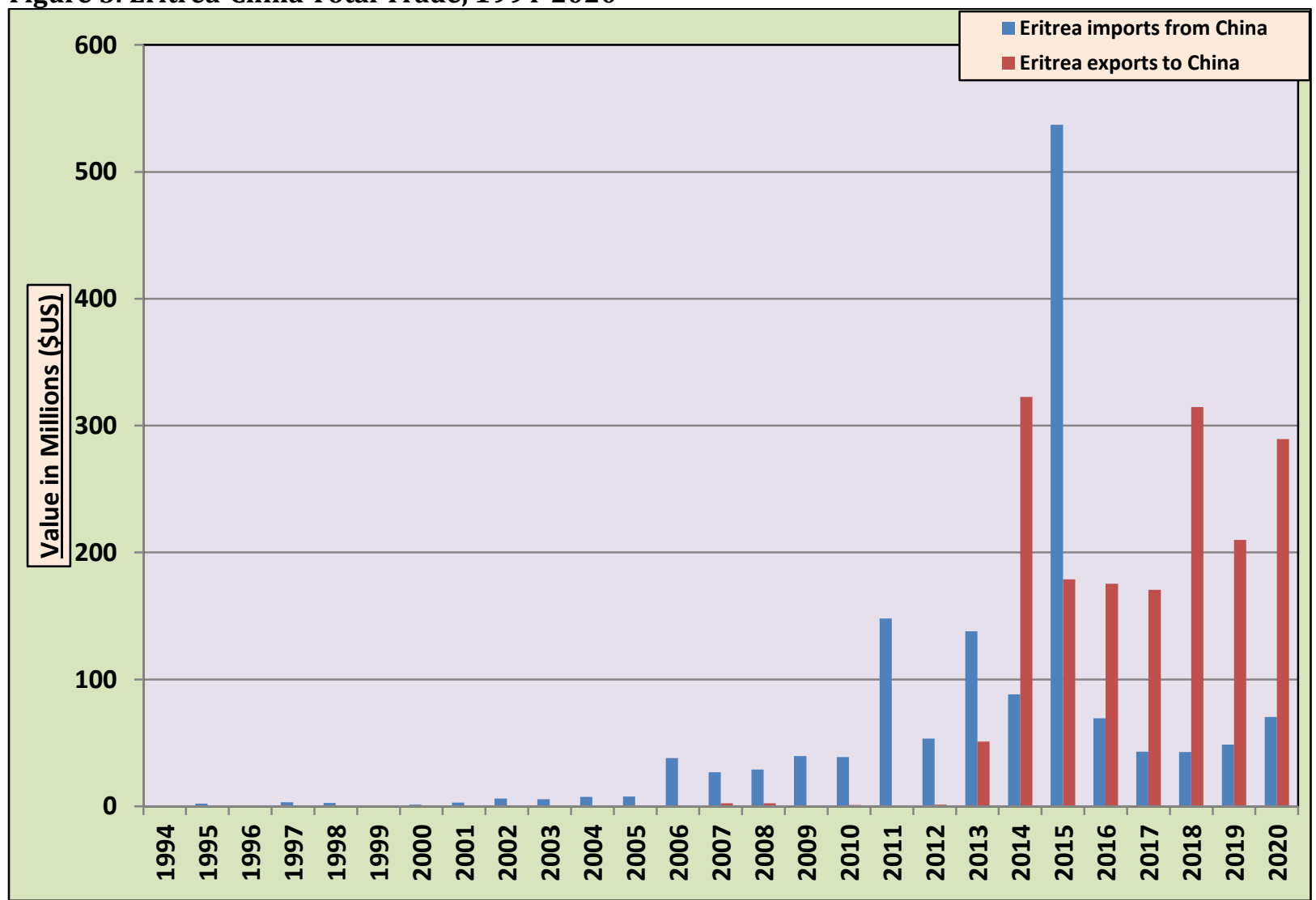

Data are retrieved from CARI (2022), which provides aggregated data on China-Africa trade from 1992 to 2019. (These data are from the UN Comtrade database.) The data for 2020 are retrieved directly from the UN Comtrade database (UN Comtrade, 2022). 
Figure 6: Eritrea: GDP per Capita and Real GDP Growth Rate, 1992-2020

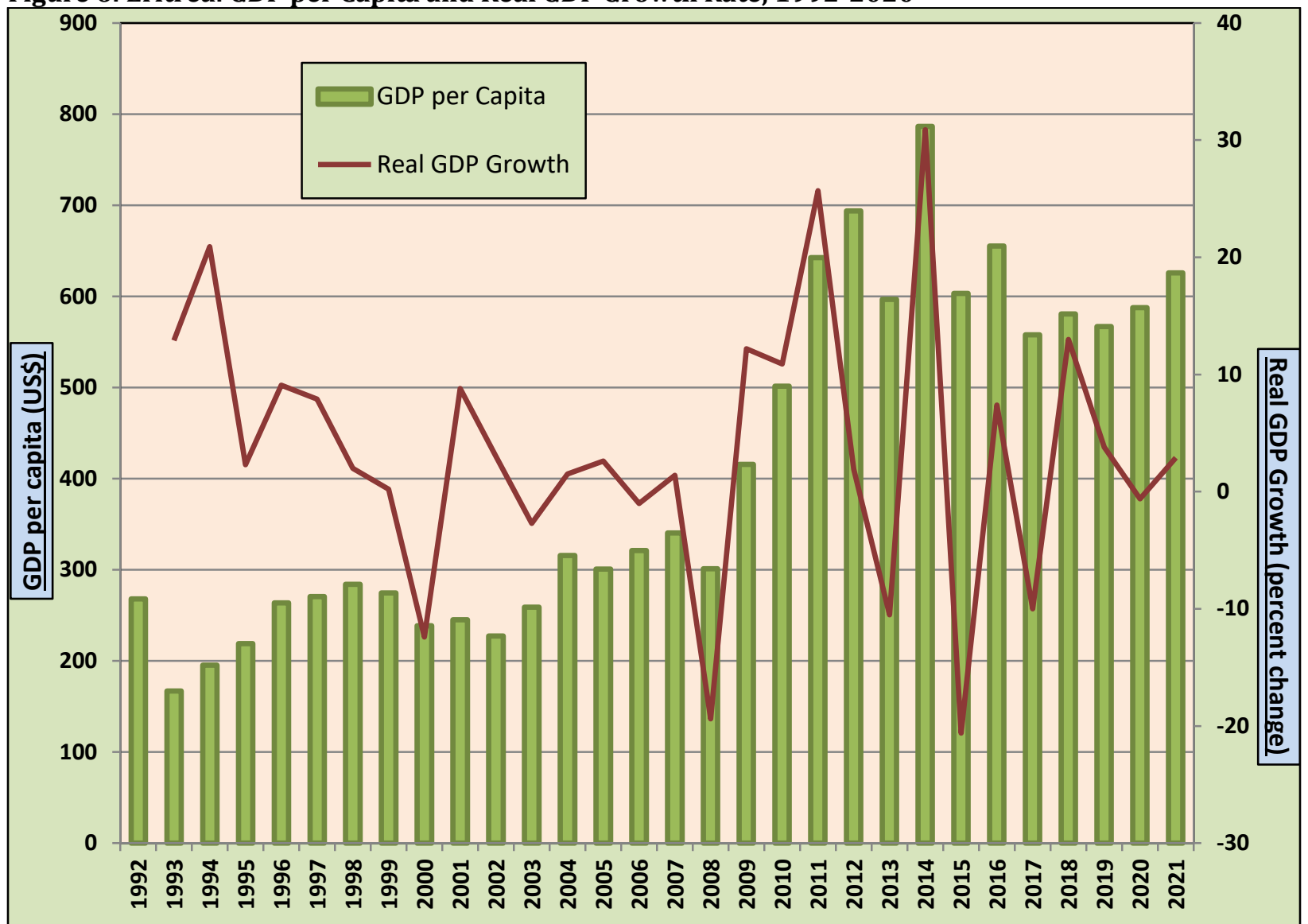

GDP per capita is presented in US dollars and current prices. Real GDP growth is presented in terms of annual percent change. The figure is based on the author's own calculations and data retrieved from IMF (2021).

Figure 7: Chinese FDI Stock in Eritrea, 2003-2019

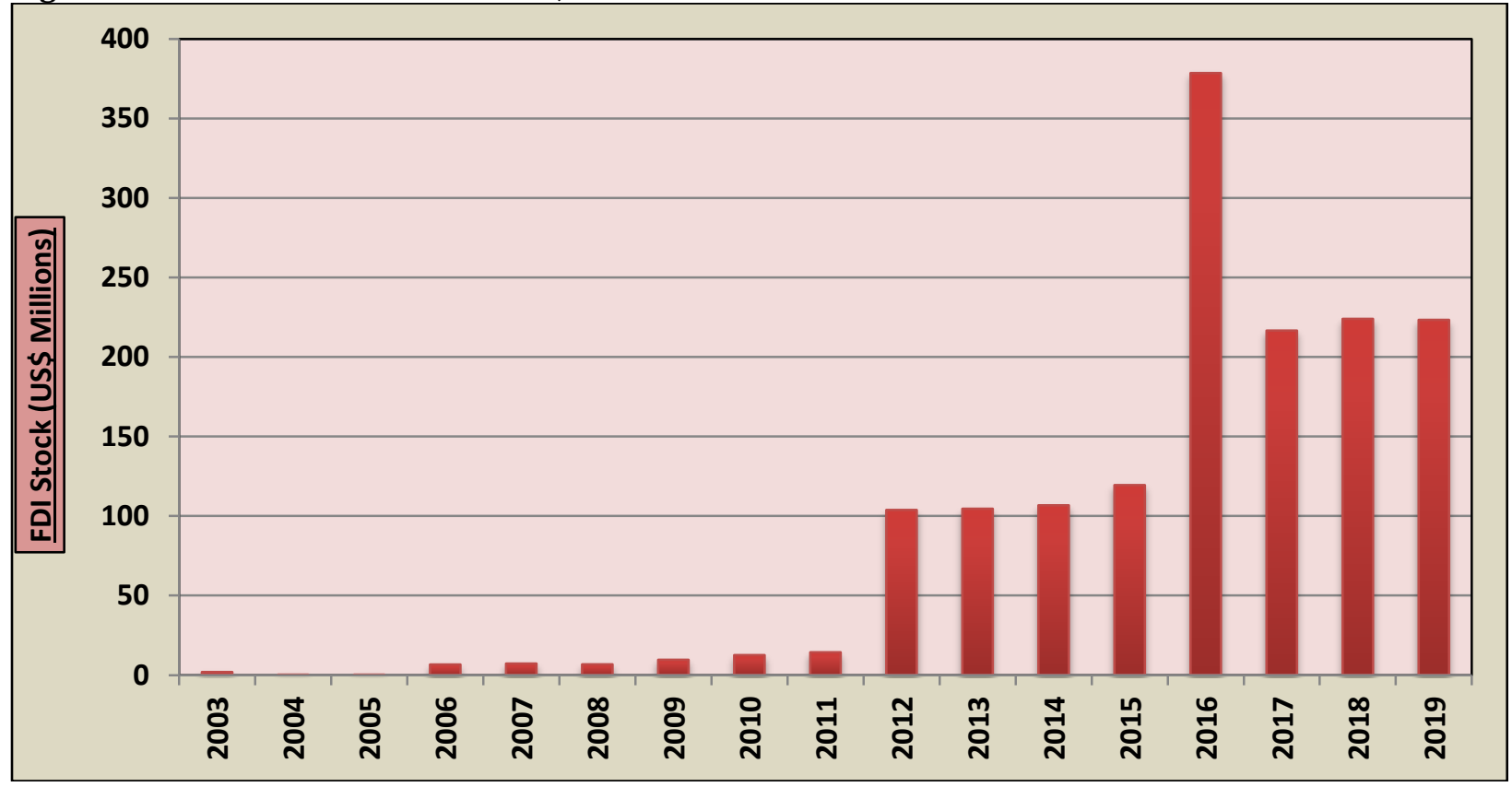

Data are retrieved from CARI (2022). 
Figure 8: Chinese Companies' Gross Revenues in Eritrea, 1998-2019

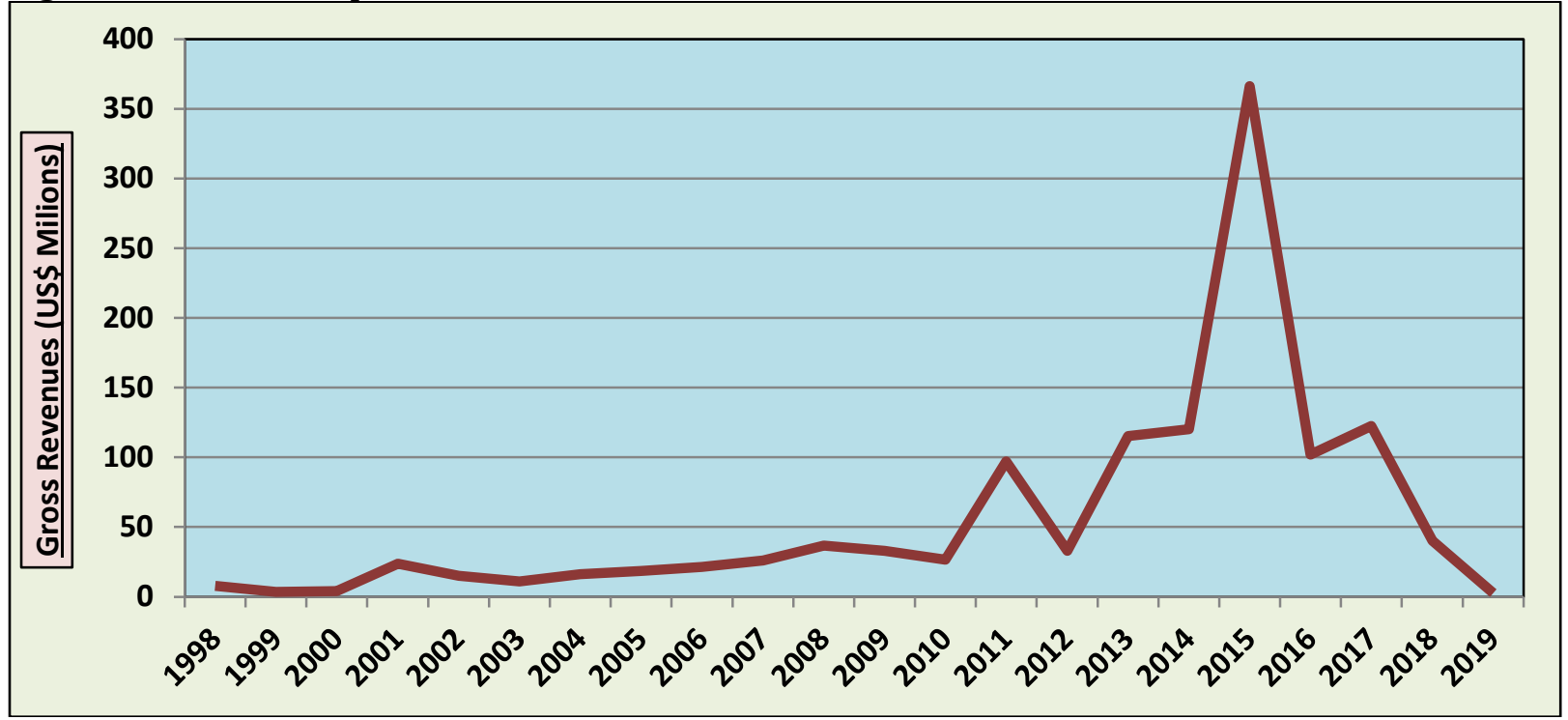

Data are retrieved from CARI (2022).

Table 1: General Perceptions about China and its Influence

\begin{tabular}{|c|c|c|c|}
\hline & $\begin{array}{l}\text { Positive or Very } \\
\text { Positive }\end{array}$ & $\begin{array}{l}\text { Neutral or } \\
\text { Don't Know }\end{array}$ & $\begin{array}{lll}\begin{array}{l}\text { Negative } \\
\text { Negative }\end{array} & \text { Very } \\
\end{array}$ \\
\hline $\begin{array}{l}\text { China's influence on the } \\
\text { world }\end{array}$ & 61 & 20 & 19 \\
\hline $\begin{array}{lll}\text { China's influence } & \text { on } \\
\text { Eritrea } & & \end{array}$ & 70 & 18 & 12 \\
\hline & $\begin{array}{l}\text { Somewhat or Very } \\
\text { Helpful }\end{array}$ & $\begin{array}{l}\text { Neutral or } \\
\text { Don't Know }\end{array}$ & $\begin{array}{l}\text { Somewhat or Very } \\
\text { Unhelpful }\end{array}$ \\
\hline $\begin{array}{l}\text { How helpful is China's } \\
\text { assistance? }\end{array}$ & 64 & 23 & 13 \\
\hline & $\begin{array}{l}\text { Somewhat or } \\
\text { Highly Satisfied }\end{array}$ & $\begin{array}{l}\text { Neutral or } \\
\text { Don't Know }\end{array}$ & $\begin{array}{l}\text { Somewhat or Highly } \\
\text { Dissatisfied }\end{array}$ \\
\hline $\begin{array}{l}\text { Satisfaction with Chinese } \\
\text { projects }\end{array}$ & 71 & 14 & 15 \\
\hline & $\begin{array}{l}\text { Agree or Strongly } \\
\text { Agree }\end{array}$ & $\begin{array}{l}\text { Neutral or } \\
\text { Don't Know }\end{array}$ & $\begin{array}{l}\text { Disagree or Strongly } \\
\text { Disagree }\end{array}$ \\
\hline $\begin{array}{ll}\begin{array}{l}\text { Chinese } \\
\text { creates jobs }\end{array} & \text { engagement }\end{array}$ & 62 & 17 & 21 \\
\hline $\begin{array}{l}\text { Chinese products and } \\
\text { services are of high quality }\end{array}$ & 18 & 11 & 71 \\
\hline
\end{tabular}

Overall $\mathrm{N}=237$ (mean age: 21.83; SD: 2.74). All figures are percentages.

Acknowledgments: The author wishes to thank all institutions and participants for their time and general assistance in the completion of this paper.

Funding Statement: There are no sources of funding to declare.

Conflicts of Interest: There are no conflicts of interest to declare. 
Human Participant Protection: Permission for the study was granted by the National Ministry of Information (Asmara, Eritrea) and all institutions. Informed consent was obtained from all participants.

\section{References}

AfDB. (2021a). African Economic Outlook: From Debt Resolution to Growth: The Road Ahead for Africa. Abidjan: African Development Bank Group.

AfDB. (2021b). Eritrea - Country Profiles - 2021. Abidjan: African Development Bank Group. Retrieved from https://www.afdb.org/en/countries/east-africa/eritrea.

Afoaku, O. G. (2000). U.S. Foreign Policy and Authoritarian Regimes: Change and Continuity in International Clientelism. Journal of Third World Studies, 17(2), 13-40.

Afrobarometer. (2016). China's Growing Presence in Africa Wins Largely Positive Popular Reviews. Afrobarometer Dispatch $\quad$ No. $122 . \quad$ Retrieved from https://www.afrobarometer.org/publications/ad122-chinas-growing-presence-africa-wins-largelypositive-popular-reviews.

Afrobarometer. (2020). Africans Regard China's Influence as Significant and Positive But Slipping. $\begin{array}{lllll}\text { Afrobarometer } & \text { Dispatch } & \text { No. } & 407 . & \text { Retrieved }\end{array}$ https://afrobarometer.org/sites/default/files/publications/Dispatches/ad407chinas_perceived_influence_in_africa_decreases-afrobarometer_dispatch-14nov20.pdf.

Afrobarometer. (2021). Africans Welcome China's Influence but Maintain Democratic Aspirations. $\begin{array}{lllll}\text { Afrobarometer } & \text { Dispatch } & \text { No. } & 489 . & \text { Retrieved }\end{array}$ https://afrobarometer.org/sites/default/files/publications/Dispatches/ad489-pap3africans_welcome_chinas_influence_maintain_democratic_aspirations-afrobarometer_dispatch15nov21.pdf.

Ahiakpor, F., Nunoo, J. \& Alnaa, S. E. (2014). A New Look at School Enrolment in Ghana: A Statistical Analysis. Journal of Studies in Education, 4(2), 42-56.

Alden, C. (2007). China in Africa. New York: Zed Books.

Asiedu, K. G. \& Kazeem, Y. (2020). Chinese Censure: Chinese workers are facing a backlash across Africa over the Guangzhou racism incidents. Quartz Africa. May 22, 2020. Retrieved from https://qz.com/africa/1860045/china-faces-african-backlash-of-guangzou-racism-incidents/.

Babbie, E. (2007). The Practice of Social Research. Belmont, CA: Wadsworth Publishing Company.

Benabdallah, L. (2016). China's Peace and Security Strategies in Africa: Building Capacity is Building Peace? African Studies Quarterly, 16(3-4), 17-34.

Benabdallah, L. (2020). Shaping the Future of Power: Knowledge Production and Network-Building in ChinaAfrica Relations. Ann Arbor: University of Michigan Press.

Bieri, F. (2010). From Blood Diamonds to the Kimberley Process: How NGOs Cleaned up the Global Diamond Industry. Burlington, VT: Ashgate Publishing Limited.

Bing, Z. \& Dashu, Q. (2018). Links with China. In S. Wynne-Jones and A. LaViolette (Eds.). The Swahili World (Pp. 294-308). New York: Routledge.

Bleakley, H. (2010). Health, Human Capital, and Development. Annual Review of Economics, 2, 283-310.

Brautigam, D. (1998). Chinese Aid and African Development. New York: St. Martin's Press.

Brautigam, D. (2009). The Dragon's Gift: The Real Story of China in Africa. New York: Oxford University Press.

Brautigam, D. (2011). China in Africa: What Can Western Donors Learn? Oslo: The Norwegian Investment Fund for Developing Countries (Norfund).

Brautigam, D. (2015). 5 Myths about Chinese Investment in Africa. Foreign Policy. December 4, 2015. Retrieved from http://foreignpolicy.com/2015/12/04/5-myths-about-chi-nese-investment-inafrica.

Brautigam, D. (2019a). A Critical Look at Chinese 'Debt-Trap Diplomacy': The Rise of a Meme. Area Development and Policy, 5(1), 1-14.

Brautigam, D. (2019b). Is China the World's Loan Shark? The New York Times. April 26, 2019. Retrieved from https://www.nytimes.com/2019/04/26/opinion/china-belt-road-initiative.html.

Brautigam, D., Diao, X., McMillan, M. \& Silver, J. (2017). Chinese Investment in Africa: How Much Do We Know? PEDL Synthesis Paper Series, 2, 1-42.

Cabestan, J. P. (2012). China and Ethiopia: Authoritarian Affinities and Economic Cooperation. China Perspectives, 4, 53-62. 
Cabestan, J. P. (2018). China's Evolving Role as a UN Peacekeeper in Mali. Washington, DC: United States Institute of Peace.

Calabrese, L. \& Tang, X. (2020). Africa's Economic Transformation: The Role of Chinese Investment. London: Development and Economic Growth Research Program.

CARI. (2022). China-Africa Research Initiative. Baltimore: School of Advanced International Studies, John Hopkins University. Retrieved from http://www.sais-cari.org/.

CGD. (2015). Better Hospitals, Better Health Systems, Better Health: Report of the Center for Global Development Hospitals for Health Working Group. Washington, DC: Center for Global Development.

Chen, S., Pender, M., Jin, N., Merson, M., Tang, S. \& Gloyd, S. (2019). Chinese Medical Teams in Africa: A Flagship Program Facing Formidable Challenges. Journal of Global Health, 9(1), 010311.

Chen, Y. J. (2019). China's Challenge to the International Human Rights Regime. International Law and Politics, $51,1179-1222$.

Chen, Y. J., Sun, I. Y., Ukaejiofo, R. U., Tang, X. \& Brautigam, D. (2016). Learning from China? Manufacturing Investment and Technology Transfer in Nigeria. SAIS-CARI Working Paper 02, 1-28.

China Foresight. (2021). FOCAC at 21: Future Trajectories of China-Africa Relations. London: London School of Economics.

China Mission. (2016). Statement by Mr. Yang Junzhi the Chinese delegation at the Interactive Dialogue with the Special Rapporteur on the situation of human rights in Eritrea at the Third Committee of the United Nations General Assembly at its $71^{\text {st }}$ session. October 27, 2016. Retrieved from http://www.china-un.org/eng/chinaandun/t1411195.htm.

China Policy Paper. (2015). Full Text: China's Second Africa Policy Paper. Retrieved from http://www.chinadaily.com.cn/world/XiattendsParisclimateconference/201512/05/content_22632874.htm.

China State Council. (2016). White Paper - China's Progress in Poverty Reduction and Human Rights. China's State Council Information Office. Retrieved from http://english.www.gov.cn/policies/latest_releases/2016/10/17/content_281475468533275.htm.

China State Council. (2019). White Paper - Seeking Happiness for People: 70 Years of Progress on Human Rights in China. China's State Council Information Office. Retrieved from http://english.www.gov.cn/archive/whitepaper/201909/22/content_WS5d87752fc6d0bcf8c4c13d 32.html.

China State Council. (2021). White Paper - China and Africa in the New Era: A Partnership of Equals. China's State Council Information Office. Retrieved from http://www.news.cn/english/202111/26/c_1310333813.htm.

Corkin, L. (2012). Chinese Construction Companies in Angola: A Local Linkages Perspective. Resources Policy, 37(4), 475-483.

Cooke, F. L., Wang, J., Yao, X., Xiong, L., Zhang, J. \& Li, A. S. (2015). Mining with a High-End Strategy: A Study of Chinese Mining Firms in Africa and Human Resources Implications. International Journal of Human Resource Management, 26(21), 2744-2762.

Creswell, J. \& Miller, D. (2000). Determining Validity in Qualitative Inquiry. Theory into Practice, 39(3), 124130.

Datar, A., Mukherji, A. \& Sood, N. (2007). Health infrastructure \& immunization coverage in rural India. Indian Journal of Medical Research, 125, 31-42.

Dollar, D. (2016). China's Engagement with Africa: From Natural Resources to Human Resources. Washington, DC: The Brookings Institution.

Dreher, A., Fuchs, A., Parks, B., Strange, A. M. \& Tierney, M. J. (2018). Apples and Dragon Fruits: The Determinants of Aid and Other Forms of State Financing from China to Africa. International Studies Quarterly, 62(1), 182-194.

Dreher, A. \& Fuchs, A. (2015). Rogue aid? An empirical analysis of China's aid allocation. Canadian Journal of Economics/Revue Canadienne d'économique, 48(3), 988-1023.

Duchâtel, M., Gowan, R. \& Rapnouil, M. L. (2016). Into Africa: China's Global Security Shift. London: The European Council on Foreign Relations.

Edwards, L. \& Jenkins, R. (2015a). The Impact of Chinese Import Penetration on the South African Manufacturing Sector. The Journal of Development Studies, 51(4), 447-463.

Edwards, Lawrence. \& Jenkins, R. (2015b). Is China 'Crowding Out' South African Exports of Manufactures? The European Journal of Development Research, 27(5), 903-920. 
Eom, J., Brautigam, D. \& Binabdallah, L. (2018). The Path Ahead: The 7th Forum on China-Africa Cooperation. Washington, DC: China-Africa Research Initiative, School of Advanced International Studies, Johns Hopkins University.

Fauvelle, F. X. (2018). The Tribulations of Two Chinese in Africa: East Africa, the Eighth to the Fifteenth Century. In F.X. Fauvele (Ed.). The Golden Rhinoceros: Histories of the African Middle Ages (pp. 1621). Princeton: Princeton University Press.

Fielding, N. (1993). Qualitative Interviewing. In N. Gilbert (Ed.), Researching Social Life (Pp. 135-153). London: Sage.

Fleurant, A., Perlo-Freeman, S., Wezeman, P. D. \& Wezeman, S. T. (2016). Trends in International Arms Transfers, 2015. SIPRI Fact Sheet. Retrieved from http://books.sipri.org/files/FS/SIPRIFS1602.pdf.

Flick, U. (2018). The SAGE Handbook of Qualitative Data Collection. Thousand Oaks, CA: SAGE.

FMPRC. (2004). Relations between China and Africa. Foreign Ministry of the People's Republic of China. January 1, 2004. Retrieved from https://www.fmprc.gov.cn/ce/ceza/eng/zghfz/zfgx/t165329.htm.

FMPRC. (2005). Position Paper of the People's Republic of China on the United Nations Reforms. Foreign Ministry of the People's Republic of China. June 7, 2005. Retrieved from https://www.fmprc.gov.cn/ce/ceindo/eng/ztbd/chinaaseanrelations/t199318.htm.

FMPRC. (2021). Wang Yi Meets with Minister of Foreign Affairs of Eritrea Osman Saleh Mohammed. Foreign Ministry of the People's Republic of China. December 2, 2021. Retrieved from https://www.fmprc.gov.cn/mfa_eng/wjdt_665385/wshd_665389/202112/t20211202_10461166.ht $\mathrm{ml}$.

FOCAC. (2021). Keynote speech by Chinese President Xi Jinping at the opening ceremony of $8^{\text {th }}$ FOCAC ministerial conference. November 29, 2021. Retrieved from http://www.focac.org/eng/ttxxsy/202112/t20211202_10461079.htm.

French, H. W. (2014). China's Second Continent: How a Million Migrants Are Building a New Empire in Africa. Knopf Doubleday Publishing Group.

Gearan, A. (2018). Bolton says 'Predatory' China is Outpacing the U.S. in Africa. New York Times. December 13, 2018. Retrieved from https://www.washingtonpost.com/politics/bolton-says-predatory-chinais-outpacing-the-us-in-africa/2018/12/13/7b906626-fee2-11e8-83c0-b06139e540e5_story.html.

Geerts, S., Xinwa, N. \& Rossouw, D. (2014). Africans' Perceptions of Chinese Business in Africa: A Survey. Geneva and Pretoria: Globethics.net and Ethics Institute of South Africa.

Giovannetti, G. \& Sanfilippo, M. (2016). Do Chinese Exports Crowd-out African Goods? An Econometric Analysis by Country and Sector. In S. Henson and O.F. Yap (Eds.). The Power of the Chinese Dragon (Pp. 10-41). London: Palgrave Macmillan.

Glewwe, P. \& Jacoby, H. (1994). Student Achievement and Schooling Choice in Low-Income Countries. Journal of Human Resource, 29(3), 843-864.

Group of Friends. (2021). Declaration of the Launch of the Group of Friends in Defense of the Charter of the United Nations. Retrieved from http://www.mppre.gob.ve/en/2021/07/07/declaration-of-thelaunch-of-the-group-of-friends-in-defense-of-the-charter-of-the-united-nations /

Haldar, S. K. \& Mallik, G. (2010). Does Human Capital Cause Economic Growth? A Case Study of India. International Journal of Economic Sciences and Applied Research, 3(1), 7-25.

Hammer, D. \& Wildavsky, A. (1989). The Open-ended, Semi-structured Interview: An (almost) Operational Guide. In Aaron Wildavsky (Ed.). Craftways: On the Organization of Scholarly Work (Pp. 57-101). New Brunswick: Transaction Publishers.

Hanauer, L. \& Morris, L. J. (2014). China in Africa: Implications of a Deepening Relationship. Santa Monica: Rand Corporation.

Handa, S. (2002). Raising Primary School Enrolment in Developing Countries: The Relative Importance of Supply and Demand. Journal of Development Economics, 63(1), 103-128.

Haroz, D. (2011). China in Africa: Symbiosis or Exploitation? The Fletcher Forum of World Affairs, 35(2), 6588.

Hodzi, O. (2018). Delegitimization and 'Re-Socialization': China and the Diffusion of Alternative Norms in Africa. International Studies, 55(4), 297-314. 
HRW. (2020). China: Covid-19 Discrimination Against Africans. New York: Human Rights Watch. May 5, 2020. Retrieved from https://www.hrw.org/news/2020/05/05/china-covid-19-discrimination-againstafricans.

Hurley, J., Morris, S. \& Portelance, G. (2018). Examining the Debt Implications of the Belt and Road Initiative from a Policy Perspective. Washington, DC: Center for Global Development.

IFAD. (2021). Eritrea. Rome: International Fund for Agricultural Development. Retrieved from https://www.ifad.org/eng/web/operations/w/country/eritrea.

International Trade Union Confederation/Global Union Federation Hong Kong Liaison Office (j). (2006). China's Exportation of Labor Practices to Africa. Retrieved from http://www.ihlo.org/CINTW/ArticleLabourPracticeExport.html.

IMF. (2021). The State of Eritrea: Country Data. Washington, DC: International Monetary Fund. Retrieved from https://www.imf.org/en/Countries/ERI\#countrydata.

Iyob, R. (1997). The Eritrean Experiment: A Cautious Pragmatism? The Journal of Modern African Studies, 35(4), 647-673.

Jinyuan, G. (1984). China and Africa: The Development of Relations over Many Centuries. African Affairs, 83(331), 241-250.

Jones, L. \& Hameiri, J. (2020). Debunking the Myth of 'Debt-Trap Diplomacy': How Recipient Countries Shape China's Belt and Road Initiative. London: The Royal Institute of International Affairs, Chatham House.

King, K. (2019). China-Africa Education Cooperation: From FOCAC to Belt and Road. East China Normal University - Review of Education, 3(2), 221-234.

Krueger, A. B. \& Lindhal, M. (2001). Education for Growth: Why and for Whom? Journal of Economic Literature, 6(2), 289-339.

Kusimba, C. M., Zhu, T. \& Kiura, P. W. (Eds.). (2020). China and East Africa: Ancient Ties, Contemporary Flows. New York: Lexington Books.

Large, D. (2016). China and South Sudan's Civil War, 2013-2015. African Studies Quarterly, 16(3-4), 35-54.

Lavy, V. (1996). School Supply Constraints and Children's Educational Outcomes in Rural Ghana. Journal of Development Economics, 51, 291-314.

Lei, W. (2020). China and the United States in Africa: Competition or Cooperation? China Quarterly of International and Strategic Studies, 6, 123-141.

Lemos, A. \& Ribeiro, D. (2007). Taking ownership or just changing owners? In F. Manji and S. Marks (Eds.). African Perspectives on China in Africa (Pp. 63-70). Nairobi: Fahamu.

Li, A. (2005). African Studies in China in the Twentieth Century: A Historiographical Survey. African Studies Review, 48(1), 59-87.

Li, A. (2007). China and Africa: Policy and Challenges. China Security, 3(3), 69-93.

Li, A. (2012). A History of Overseas Chinese in Africa to 1911. New York: Diasporic Africa Press.

Li, Q. \& Ye, M. (2019). China's Emerging Partnership Network: What, Who, Where, When and Why. International Trade, Politics and Development, 3(2), 66-81.

Lin, S., Gao, L., Reyes, M., Cheng, F., Kaufman, J. \& El-Sadr, W. M. (2016). China's Health Assistance to Africa: Opportunism or Altruism? Globalization and Health, 12, 83-88.

Lin, J. Y. (2011). From Flying Geese to Leading Dragons: New Opportunities for Structural Transformation in Developing Countries. Policy Research Working Paper Series, 5313. Washington, DC: The World Bank.

Lyman, P. (2006). China's Involvement in Africa: A View from the US. South African Journal of International Affairs, 13(1), 129-138.

Markakis, J. (1988). The Nationalist Revolution in Eritrea. The Journal of Modern African Studies, 26(1), 51-70.

Marrufob, G. M. (2007). Can Better Infrastructure and Quality Reduce Hospital Infant Mortality Rates in Mexico? Health Policy, 80(2), 239-252.

McGreal, C. (2007). Thanks China, now go home: buy-up of Zambia revives old colonial fears. The Guardian. February 5, 2007. Retrieved from https://www.theguardian.com/world/2007/feb/05/china.chrismcgreal.

MFA. (2015). Statement by Xi Jinping, President of the People's Republic of China, at the General Debate of the $70^{\text {th }}$ Session of the UN General Assembly. United Nations, New York. Retrieved from https://gadebate.un.org/sites/default/files/gastatements/70/70_ZH_en.pdf. 
Ministry of Health and UNDP. (2014). Health Millennium Development Goals Report: Innovations Driving Health MDGs in Eritrea. Asmara, Eritrea: Ministry of Health and United Nations Development Program.

Miriri, D. (2022). China plans peace envoy for conflict-riven Horn of Africa. Reuters. January 6, 2022. Retrieved from https://www.reuters.com/world/china/china-appoint-special-envoy-horn-africa2022-01-06/.

Morris, A. (2015). A Practical Introduction to In-depth Interviewing. London: Sage.

Moyo, D. (2012). Beijing, a Boon for Africa. The New York Times. June 27, 2012. Retrieved from http://www.nytimes.com/2012/06/28/opinion/beijing-a-boon-for-africa.html.

Nantulya, P. (2021). China's Role in COVID-19 in Africa: Tuánjié (Solidarity) or Zhànlüè (Strategy)? September 8, 2021. Durban, South Africa: ACCORD. Retrieved from https://www.accord.org.za/analysis/chinasrole-in-covid-19-in-africa-tuanjie-solidarity-or-zhanlue-strategy/.

Newing, H. (2011). Qualitative Interviews and Focus Groups. In Helen Newing (Ed.). Conducting Research in Conservation: Social Science Methods and Practice (Pp. 98-118). New York: Routledge.

Obiorah, N. (2007). Who's afraid of China in Africa? Towards an African civil society perspective on ChinaAfrica relations. In F. Manji and S. Marks (Eds.). African Perspectives on China in Africa (Pp. 35-55). Nairobi: Fahamu.

OHCHR. (2019). United Nations Human Rights Council: Enhanced Interactive Dialogue on the Situation of Human Rights in Eritrea. March 11, 2019. Retrieved from https://www.ohchr.org/EN/NewsEvents/Pages/DisplayNews.aspx?NewsID=24306\&LangID=E.

Ottaway, M. \& Ottaway, D. (1978). Ethiopia: Empire in Revolution. New York: Holmes and Meier Publishers.

Owen IV, J. M. \& Poznansky, M. (2014). When Does America Drop Dictators? European Journal of International Relations, 20(4), 1072-1099.

Peterson, B. B. (1994). The Ming Voyages of Cheng Ho (Zheng He), 1371-1433. The Great Circle, 16(1), 43-51.

Pew Research Center. (2019). Attitudes toward China. December 5, 2019. Retrieved from https://www.pewresearch.org/global/2019/12/05/attitudes-toward-china-2019/.

Phillips, M. M. (2021). China Seeks First Military Base on Africa's Atlantic Coast, U.S. Intelligence Finds. The Wall Street Journal. December 5, 2021. Retrieved from https://www.wsj.com/articles/china-seeksfirst-military-base-on-africas-atlantic-coast-u-s-intelligence-finds-11638726327.

Polgreen, L. \& French, H. W. (2007). In Africa, China is Both Benefactor and Competitor. The New York Times. August 20, 2007. Retrieved from https://www.nytimes.com/2007/08/20/world/africa/20cndzambia.html.

Pose, R. R. \& Samuels, F. (2011). Progress in Health in Eritrea: Cost-Effective Inter-Sectoral Interventions and a Long-Term Perspective. London: Overseas Development Institute.

Quinn, A. (2011). Clinton Warns Against 'New Colonialism' in Africa. Reuters. June 11, 2011. Retrieved from http://www.reuters.com/article/us-clinton-africaidUSTRE75A0RI20110611.

Rebol, M. (2010). Public Perceptions and Reactions: Gauging African Views of China in Africa. African Journal of Agricultural Research, 5(25), 3524-3535.

Regilme Jr., S. S. F. \& Hodzi, O. (2021). Comparing the US and Chinese Foreign Aid in the Era of Rising Powers. The International Spectator, 56(2), 114-131.

Rocha, J. (2007). A New Frontier in the Exploitation of Africa's Natural Resources: The Emergence of China. In F. Manji and S. Marks (Eds.). African Perspectives on China in Africa (Pp. 15-34). Nairobi: Fahamu.

RSA. (2018). Remarks by President Cyril Ramaphosa during the Forum on China-Africa Cooperation (FOCAC) Opening Ceremony in Beijing, China. The Presidency, Republic of South Africa. September 3, 2018. Remarks from https://www.thepresidency.gov.za/speeches/remarks-president-cyril-ramaphosaduring-forum-china-africa-cooperation-focac-opening.

Rudolf, M. (2021). China's Health Diplomacy during Covid-19: The Belt and Road Initiative (BRI) in Action. Stiftung Wissenschaft und Politik, 9, 1-8.

Ryder, H. \& Fu, Y. (2021). Africa's 'Too Little Debt' Crisis: Why Finance from China to African Countries is More Crucial than Ever in the Wake of COVID-19. China International Strategy Review, 1-17.

Sautman, B. \& Hairong, Y. (2009). African Perspectives on China-Africa Links. The China Quarterly, 199 728759.

Shabait. (2015). Statement by Osman Saleh, Minister of Foreign Affairs of the State of Eritrea, on Human Rights Day. Asmara. Retrieved from https://shabait.com/2016/03/19/statement-of-ministerosman-saleh-on-human-rights-day-2015/. 
Shabait. (2016a). Statement by Osman Saleh, Minister of Foreign Affairs of the State of Eritrea, at the $70^{\text {th }}$ Session of the United Nations General Assembly. United Nations, New York. Retrieved from https://shabait.com/2016/03/18/statement-by-he-mr-osman-saleh-2/.

Shabait. (2016b). Statement by Girma Asmerom, Permanent Representative of the State of Eritrea, during the High-Level Dialogue on Human Rights, 12-13 July 2016. Retrieved from https://shabait.com/2016/07/14/statement-by-he-ambassador-girma-asmerom-the-permanentrepresentative-of-eritrea-during-the-high-level-dialogue-on-human-rights-12-13-july-2016/.

Shabait. (2018). Press Statement: Eritrea's Election to the United Nations Human Rights Council. Retrieved from https://shabait.com/2018/10/17/eritreas-election-to-the-united-nations-human-rightscouncil/.

Shabait. (2022a). Eritrea and China Agree to Strengthen Strategic Partnership. Shabait. January 5, 2022. Retrieved from https://shabait.com/2022/01/05/eritrea-and-china-agree-to-strengthen-strategicpartnership/.

Shabait. (2022b). Joint Statement by Foreign Ministers of the State of Eritrea and the People's Republic of China. Shabait. January 5, 2022. https://shabait.com/2022/01/05/joint-statement-by-foreignministers-of-the-state-of-eritrea-and-the-peoples-republic-of-china/.

Shangwe, M. (2017). China's Soft Power in Tanzania: Opportunities and Challenges. China Quarterly of International Studies, 3(1), 79-100.

Shaomin, X. \& Jiang, L. (2020). The Emergence and Fallacy of 'China's Debt-Trap Diplomacy' Narrative. China International Studies, 81, 69-84.

Shinn, D. H. \& Eisenman, J. (2012). China and Africa: A Century of Engagement. Philadelphia: University of Pennsylvania.

Shurkin, M., Noyes, A. \& Adgie, M. K. (2021). The COVID-19 Pandemic in Sub-Saharan Africa: An Opportunity to Rethink Strategic Competition on the Continent. Santa Monica, CA: Rand Corporation.

Sigalla, H. (2014). Changing Trends in the Tanzania-China Relationship. Österreichische Zeitschrift für Sociologi, 39(1), 61-78.

Smidt, W. G. C. (2001). A Chinese in the Nubian and Abyssinian Kingdoms ( $8^{\text {th }}$ Century): The visit of Du Huan to Molin-guo and Laobosa. Chroniques yéménites, 9, 17-28.

Smith, P. (2000). Talons of the Eagle: Dynamics of U.S.-Latin American Relations. New York: Oxford University Press.

Snow, P. (1989). The Star Raft: China's Encounter with Africa. Ithaca, NY: Cornell University Press.

Snyder, H. (2019). Literature Review as a Research Methodology: An Overview and Guidelines. Journal of Business Research, 104(2019), 333-339.

Stein, P. \& Uddhammar, E. (2021). China in Africa: The Role of Trade, Investments, and Loans Amidst Shifting Geopolitical Ambitions. New Delhi: Observer Research Foundation.

Strüver, G. (2016). What friends are made of bilateral linkages and domestic drivers of foreign policy alignment with China? Foreign Policy Analysis, 12(2), 170-191.

Sun, I. Y., Jayaram, K. \& Kassiri, O. (2017). Dance of the Lions and Dragons: How are Africa and China Engaging, and How Will the Partnership Evolve? Washington, DC: McKinsey \& Company.

Sun, Y. (2014). Africa in China's Foreign Policy. Washington, DC: The Brookings Institution.

Sweetland, S. R. (1996). Human Capital Theory: Foundations of a Field of Inquiry. Review of Educational Research, 66(3), 341-359.

Tang, X. (2016). Does Chinese Employment Benefit Africans? Investigating Chinese Enterprises and their Operations in Africa. African Studies Quarterly, 16(3-4), 107-128.

Taylor, I. (1998). China's Foreign Policy towards Africa in the 1990s. Journal of Modern African Studies, 36(3), 443-460.

Taylor, I. (2004). The 'all-weather friend'? Sino-African Interaction in the Twenty-First Century. In I. Taylor and P. Williams (Eds.). Africa in International Politics: External Involvement on the Continent (Pp. 83-101). London: Routledge.

Taylor, I. (2006). China and Africa: Engagement and Compromise. London: Routledge.

Taylor, I. (2010). A Challenge to the Global Liberal Order: The Growing Chinese Relationship with Africa. In S. Breslin (Ed.). Handbook of China's International Relations (Pp. 187-199). Abingdon: Routledge.

The Economist. (2010). Ethiopia and China: Looking East. The Economist. October 21, 2010. Retrieved from https://www.economist.com/middle-east-and-africa/2010/10/21/looking-east. 
The Economist. (2021). Harboring No Malice? America Worries about China's Military Ambitions in Africa. The Economist. December 9, 2021. Retrieved from https://www.economist.com/china/2021/12/09/america-worries-about-chinas-militaryambitions-in-africa.

Tugendhat, H. \& Voo, J. (2021). China's Digital Silk Road in Africa and the Future of Internet Governance. Working Paper No. 2021/50, Washington, DC: China Africa Research Initiative, School of Advanced International Studies, Johns Hopkins University.

Tull, D. M. (2006). China's Engagement in Africa: Scope, Significance and Consequences. Journal of Modern African Studies, 44(3), 459-479.

UN Comtrade. (2022). UN Comtrade Database. Retrieved from https://comtrade.un.org/.

UN Eritrea. (2017). Delivering as One for the SDGs: The Strategic Partnership Cooperation Framework (SPCF) Between the Government of the State of Eritrea and the United Nations. Asmara, Eritrea: Eritrea Ministry of National Development and United Nation Eritrea Office.

UN HRC. (2014). United Nations Human Rights Council: Universal Periodic Review Report Consideration. 41 $1^{\text {st }}$ Meeting. 25th Regular Session. March 20, 2014. Retrieved from http://webtv.un.org/meetingsevents/watch/china-upr-report-consideration-41st-meeting-25th-regular-session-human-rightscouncil/3369309459001.

Vartanian, T. P. (2011). Secondary Data Analysis. Oxford: Oxford University Press.

Wade, A. (2008). Time for the West to Practice What It Preaches. The Financial Times. January 23, 2008. Retrieved from https://www.ft.com/content/5d347f88-c897-11dc-94a6-0000779fd2ac.

Warmerdam, W. \& Van Dijk, M. P. (2016). Chinese Traders in Kampala: Status, Challenges, and Impact on Ugandan Society. African Studies Quarterly, 16(3-4), 129-148.

Waweru, S. M. (2021). Who is Against Sino-African Relations? Evolving Perceptions on Chinese Engagement in Kenya. Chinese Journal of International Review, 2(2), 1-22.

Wei, S. (1999). Some Reflections on the One-China Principle. Fordham International Law Journal, 23(4), 11691178.

Were, A. (2018). Debt Trap? Chinese Loans and Africa's Development Options. South African Institute of International Affairs, Policy Insights, 66, 1-13.

White Paper. (2000). White Paper: The One-China Principle and the Taiwan Issue. Taiwan Affairs Office and the Information Office of the State Council. February 21, 2000. Retrieved from http://www.taiwandocuments.org/white.htm.

WHO. (2018). Country Cooperation Strategy: At a Glance - Eritrea. Geneva: World Health Organization.

WHO, OECD, and World Bank. (2018). Delivering Quality Health Services: A Global Imperative for Universal Health Coverage. Geneva: World Health Organization, Organization for Economic Co-operation and Development, and the World Bank Group.

World Bank. (2021a). Press Release: Amid Recession, Sub-Saharan Africa Poised for Recovery. Washington, DC: The World Bank Group. Retrieved from https://www.worldbank.org/en/news/pressrelease/2021/03/31/amid-recession-sub-saharan-africa-poised-for-recovery.

World Bank. (2021b). Eritrea Overview: Context, Strategy, Results, Partners. Washington, DC: The World Bank Group. Retrieved from www.worldbank.org./en/country/eritrea/overview.

Xinhua. (2017). Socialism with Chinese Characteristics Enters a new Era. Xinhua. October 18, 2017. Retrieved from http://www.xinhuanet.com/english/2017-10/18/c_136688475.htm.

Xinhua. (2019). Ambassadors from 37 countries issue joint letter to support China on its human rights achievements. Xinhua. July 13, 2019. Retrieved from http://www.xinhuanet.com/english/201907/13/c_138222183.htm.

Xinhua. (2020). Full text: Keynote speech by President Xi Jinping at Extraordinary China-Africa Summit on Solidarity against COVID-19. Xinhua. June 18, 2020. Retrieved from http://www.xinhuanet.com/english/2020-06/18/c_139147084.htm.

Yin, R. K. (2003). Case Study Research: Design and Methods. (3 ${ }^{\text {rd }}$ Edition). Thousand Oaks, CA: Sage Publications.

Zafar, A. (2007). The Growing Relationship between China and Sub-Saharan Africa: Macroeconomic, Trade, Investment, and Aid Links. The World Bank Research Observer, 22(1), 103-130.

Zürcher, C. (2019). 30 Years of Chinese Peacekeeping. Ottawa: Centre for International Policy Studies and the University of Ottawa. 


\section{Endnotes}

${ }^{1}$ The "One-China Principle", sometimes referred to as the "One-China Policy", is a principle asserted by the Chinese government declaring that, "there is only one China in the world, Taiwan is a part of China and the government of the PRC is the sole legal government representing the whole of China" (Wei, 1999; White Paper, 2000).

${ }^{2}$ China may also have another advantage vis-à-vis the West and Africa's receptivity to cooperation: it does not have the West's fraught legacy in Africa (e.g., slavery and colonialism), which may engender a crisis in legitimacy for the West in Africa that China can leverage to its advantage (Were, 2018).

${ }^{3}$ For instance, during 2006 elections in Zambia, the late Michael Sata, an opposition candidate, campaigned on an anti-China platform and claimed that, "Their [China's] interest is exploiting us, just like everyone who came before. They have simply come to take the place of the West as the new colonizers of Africa" (Polgreen and French, 2007). However, it is worth recalling that China has no history of colonialism, nor does it have an extensive history of invading other states. Moreover, many of the criticisms are often tinged with hypocrisy, since they may equally apply to Western states as well. Last, criticisms must also be placed firmly within the context of the growing and rapidly intensifying US-China rivalry for global influence, as well as China's surging presence in Africa, which has raised competition and posed challenges for the US (Campbell, 2008; Lei, 2020).

${ }^{4}$ One of the most well-known projects from this period was the nearly 2000-kilometer-long Tan-Zam Railway, which linked landlocked Zambia with the Port of Dar es Salaam in Tanzania. Constructed between 1968 and 1976, the project was China's largest turn-key foreign aid project at the time (Snow, 1989; Sun et al., 2017; Taylor, 1998).

In terms of loans, it should be pointed out that the figures presented are not to be regarded as equivalent to African government debt, as the source, the China Africa Research Initiative, does not track disbursement or repayment (CARI, 2022). Notably, as a result of Africa's growing levels of debt owed to China, criticisms have been raised about "debt diplomacy" and potential asset seizures. With many Chinese-backed projects lacking profitability, there are concerns that overburdened countries will struggle to service loans and become politically beholden to China. However, these concerns are generally not empirically supported and a large body of research suggests Chinese loans are not a major contributor to debt distress in Africa. Also worth noting is that the secrecy surrounding many contracts makes it difficult to judge conclusively (Brautigam, 2019a; 2019b; Eom, Brautigam, and Benabdallah, 2018).

${ }^{6}$ Coronavirus disease (COVID-19) is an infectious disease caused by a recently discovered coronavirus. On 31 December 2019, Chinese media reported for the first time on an outbreak of viral pneumonia in the city of Wuhan. Months later, in early March 2020, COVID-19 was declared a pandemic by the World Health Organization, with Africa reporting its first case in mid-February 2020.

${ }^{7}$ China's support to Africa has been driven by several different motives, including altruism, geopolitical aims, an attempt to divert attention away from the alleged origin of the virus in China, seeking to lay the groundwork for future partnerships, and attempting to showcase itself as a responsible global leader and reliable partner during crises (Rudolf, 2021).

${ }^{8}$ The military base in Djibouti, which hosts several thousand personnel and is operated by the People's Liberation Army Navy Marine Corps, includes a pier that can accommodate an aircraft carrier, a large assault vessel, and other military vessels.

${ }^{9}$ While there are no reliable data on the number of Chinese migrants or workers in Africa, in the past about one million Chinese migrants was a commonly used estimate (Dollar, 2016: 73; French, 2014).

${ }^{10}$ Of course, many Western countries also extend support to authoritarian regimes and overlook their deplorable human rights situations, driven by political and security interests.

${ }^{11}$ China regards its own development path as an example that other developing countries can learn from. At the opening of the $19^{\text {th }}$ National Congress of the Communist Party of China, Xi Jinping explained that the Chinese model, "offers a new option for other countries and nations who want to speed up their development while preserving their independence" (Xinhua, 2017).

${ }^{12}$ As wages and costs in China rise, manufacturing will likely gradually shift to lower cost regions, including Africa (Dollar, 2016; Lin, 2011; Sun, 2014).

${ }^{13}$ The influx of goods may also induce "creative destruction" or technology transfer.

${ }^{14}$ Again, however, there are elements of double standards and politicization to these criticisms. In particular, many Western countries have a long history of financing and supporting dictators and authoritarian regimes, 
mainly in pursuit of advancing their geostrategic and political interests (Afoaku, 2000; Owen IV and Poznansky, 2014; Smith, 2000).

${ }^{15}$ Generally, China's approach to funding overseas projects is to follow the rules and regulations of the country in which it is investing, which can be problematic when recipient countries have poor standards and regulations (Dollar, 2016: 66-67). Notably, in a 2012 New York Times op-ed, Dambisa Moyo, a Zambian economist, argued that, "the bulk of responsibility for abuses lies with African leaders themselves" (Moyo, 2012).

${ }^{16}$ Several items in Eritrea's national museums also suggest extremely early connections, while a large body of work has demonstrated considerable historical contact between China and the broader region (Fauvelle, 2018; Kusimba, Zhu, and Kiura, 2020; Li, 2012; Smidt, 2001).

${ }^{17}$ The ELF began the armed struggle for independence, before being superseded by the Eritrean People's Liberation Front (EPLF). Estimates suggest about five hundred Chinese automatic weapons were received.

${ }^{18}$ Within the context of Sino-Soviet tensions, as the Derg heavily relied on support from the USSR, the EPLF received several Chinese overtures. However, the EPLF refused to meet Chinese conditions and no aid was forthcoming.

${ }^{19}$ Such as gold and cement production at the Zara mine and Gedem Cement Plant, respectively.

${ }^{20}$ In 2018, the Zijin Mining Group Company acquired Nevsun following a friendly takeover offer of around \$US1.41 billion. Additionally, while Eritrea's state-owned ENAMCO held a 40 percent interest in the Bisha mine for many years, in April 2019 it acquired a further 5 percent interest for around \$US10 million.

${ }^{21}$ Over the years, China has established a number of special partnerships with other countries and organizations. Partnerships are classified hierarchically, with levels corresponding to the importance that Beijing attaches to each partner, the substance of China's relations with that country or organization, and other factors (Li and Ye, 2019; Strüver, 2017).

${ }^{22}$ The UN Security Council imposed sanctions on Eritrea in December 2009 over the government's alleged role in insecurity in the Horn of Africa. The sanctions were broadened in 2011, before being lifted in November 2018. 